\title{
Checklist of freshwater symbiotic temnocephalans (Platyhelminthes, Rhabditophora, Temnocephalida) from the Neotropics
}

\author{
Andrés Martínez-Aquino ${ }^{1}$, Francisco Brusa $^{1}$, Cristina Damborenea $^{1}$ \\ 1 División Zoología Invertebrados, Museo de La Plata, FCNyM, UNLP, Paseo del Bosque s/n, 1900 La Plata, Argentina \\ http://zoobank.org/286A18D5-FBB4-47E8-93D2-778718848F14 \\ Corresponding author: Cristina Damborenea (cdambor@fcnym.unlp.edu.ar)
}

\begin{abstract}
Received 20 July 2014

Accepted 1 September 2014

Published 10 October 2014

Academic editor:

David Gibson

\section{Key Words}

Temnocephala

Didymorchis

Diceratocephala

Based on published records and original data derived from our research, we have generated a checklist of symbiotic temnocephalan fauna from 57 taxa of freshwater invertebrate and vertebrate hosts from 16 families included in four classes from the Neotropics. The checklist contains 38 nominal species from 3 genera belonging to the Temnocephalida families Diceratocephalidae, Didymorchidae and Temnocephalidae. All taxa (35) of the genus Temnocephala are endemic to the Neotropics and 14 (40\%) are considered microendemic (i.e. only one record each from a single locality). While only one species and one variety of Didymorchis are known from the Neotropics; there are also two putative undescribed species of this genus. Only Diceratocephala boschmai (Diceratocephalidae) is reported as an introduced species from Uruguay. Host specificity to a particular group of invertebrates and vertebrates is the first evidence for the ecological and evolutionary associations that will be analyzed in future studies.
\end{abstract}

Malacostraca

Insecta

Gastropoda

Chelonia

taxonomy

inventory

\section{Introduction}

Temnocephalida (Platyhelminthes, Rhabditophora) is the most diverse group of symbiotic turbellarians typically associated with crustaceans, with 122 valid species and 24 genera described in the world (Tyler et al. 2006-2012). Recently, Temnocephalida was confirmed as a monophyletic group included in Lymnotyphloplanida, which in turn makes up part of the Dalytyphloplanida clade, a major group of Rhabdocoela (Van Steenkiste et al. 2013). Within the Temnocephalida, the family Temnocephalidae Monticelli, 1899, is the most diverse, distributed in the Australian region with high species richness, but low host diversity, and in the Neotropics with an apparently lower number of temnocephalan species, but a greater diversity of host taxa (Damborenea and Brusa 2009, Sewell 2013). In fact, in the Neotropics, 32 species belonging to the genus Temnocephala and four taxa belonging to Didymorchis, endemic to this region and associated with crustaceans, mollusks, insects and chelonians have been described (Damborenea and Cannon 2001b, Garcés et al. 2013 and cited therein).

The inventory work of the temnocephalan fauna in the Neotropics began in the $18^{\text {th }}$ century, when the first species of Temnocephalida was described, Temnocephala chilensis (Moquin-Tandon 1846), associated with anomuran crabs, Aegla laevis (Latreille), from Chile (Damborenea and Cannon 2001a). Since then, more than 50 studies have been published regarding aspects of the temnocephalan fauna in the Neotropics, including descriptions of new species, analyses of temnocephalan symbiotic community structure of particular host species, and studies with phylogenetic and biogeographic inferences (e.g. Damborenea 1998, Volonterio 2007a, 
Garcés et al. 2013). However, in many cases, information about the reported biodiversity in particular geographical locations of these rabdocoel turbellarians is scattered among myriad bibliographic sources and difficult to access. Therefore, attempts to generate inventories and compile information are highly valuable for understanding the global diversity of freshwater flatworms (Schockaert et al. 2008). The main objectives of this paper are to compile all the available published accounts on the symbiotic freshwater temnocephalans from the Neotropics and to incorporate new data derived from our own work of the last few years to construct a checklist of symbiont-host associations.

\section{Material and methods}

\section{Bibliographic search}

All the published records on Neotropical temnocephalan species reported from Malacostraca (Decapoda), Gastropoda (Caenogastropoda), Insecta (Hemiptera, Megaloptera, Plecoptera and Trichoptera) and Reptilia (Testudines) strictly in freshwater systems were compiled. Databases such as Biological Abstracts, Biological and Agricultural Index Plus and Scopus, Google Scholar, Helminthological Abstracts, ISI Web of Knowledge, Turbellarian Taxonomic Database and Zoological Record were used to ensure that we retrieved all available information; the bibliographic search was undertaken up to June, 2014. We considered all the studies whose datasets provide taxonomic information regarding the Neotropical temnocephalan taxa, even those found in a single individual host. Papers containing compiled records of Neotropical temnocephalans that require taxonomic revisions due to problems were indicated (e.g. Vianna and Melo 2002). The host species names were used according with IUCN (2014), Tree of Life Web Project (Maddison and Schulz 2007), and with specific bibliography for Gastropoda (Cowie and Thiengo 2003) and Malacostraca (Melo 2003, De Grave and Ashelb 2013). Furthermore, a species accumulative curve (Dove and Cribb 2006) was obtained to evaluate the extent of the Neotropical symbiotic temnocephalan inventory.

\section{Survey work}

Original data from our own studies of the last few years were included. A total of 11 taxa of decapod crustaceans of five families was examined for Argentine and Mexican temnocephalans. Furthermore, two species of Chelonia and one of Gastropoda from Argentina also were examined. Decapod crustaceans were collected with seine nets in one locality of central Mexico (Table 1). The collected decapod crustaceans were kept alive and examined for temnocephalans no more than $4 \mathrm{~h}$ after their capture. Decapod crustaceans were sacrificed and immediately examined for temnocephalans; external (e.g. carapace and claw surface) and internal structures (e.g. branchial cavity) were analyzed separately in Petri dishes with $0.65 \%$ saline solution, under a stereomicroscope. Gills from each decapod were also obtained and placed in tap water to search for temnocephalans. In the case of mollusk hosts, their mantle cavity was opened after sacrificing. Temnocephalan collections from live turtles were carried out by the catch-andrelease method (e.g. FAO 2012); therefore, the live turtles were identified directly in the field (L. Alcalde, personal communication). Temnocephalans were fixed with hot (steaming) 4\% formalin or hot (steaming) distilled water. In some cases, specimens from the same host and with the same external aspect were fixed in $100 \%$ ethanol in the field for future molecular studies. All temnocephalans were processed following standard procedures (Sewell 2013). Species identification was achieved using specialized literature, and voucher specimens of some temnocephalans were deposited at the Colección Helmintológica of Museo de La Plata, Argentina (MLP-He) and the Colección Nacional de Helmintos (CNHE), Instituto de Biología, Universidad Nacional Autónoma de México (UNAM), Mexico City, Mexico, as follows: symbionts of Malacostraca (CNHE: 9276-9277; MLP-He: 6148-6155, 6218, 6641, $6763,6768,6770,7153$ ); symbionts of Gastropoda (MLPHe: 3050-3052, 6622, 6764-6767, 6769) and symbionts of Chelonia (MLP-He: 6642-6643).

\section{Results}

In total, 60 papers have been published establishing host and locality records of the freshwater temnocephalan fauna in the Neotropics. The analysis of all available information (bibliographic and new original data) allowed us to establish a list of 38 symbiotic temnocephalan taxa in invertebrates and vertebrates in the Neotropical region, which are contained in four groups of hosts. Malacostraca (Decapoda): 4 taxa of Didymorchis associated with 3 taxa of crabs, 17 species of Temnocephala associated with 32 taxa of decapod crustaceans and only one species of $\mathrm{Di}$ ceratocephala associated with one species of decapod crustacean; Gastropoda (Caenogastropoda): 5 species of Temnocephala associated with 5 taxa of freshwater snail hosts; Insecta: 1, 2, 2 and 1 taxa of Temnocephala associated with 1, 5, 3 and 1 taxa hosts of Trichoptera, Hemiptera, Megaloptera and Plecoptera, respectively; Chelonia (Testudines): 4 taxa of Temnocephala associated with 7 species of freshwater turtle hosts.

The results of this study are presented in the Table 1 which shows the symbiont-host list, where temnocephalans are organized by taxonomic groups and ordered alphabetically by family name. Then species within each family are listed alphabetically followed by authority name and date. The next category is the host species in which the temnocephalids were found, followed by the locality, and the bibliographic reference from which the information was obtained, except for those records established in the present work. In the temnocephalan species found in more than one host species, the latter are listed alphabetically, and host 


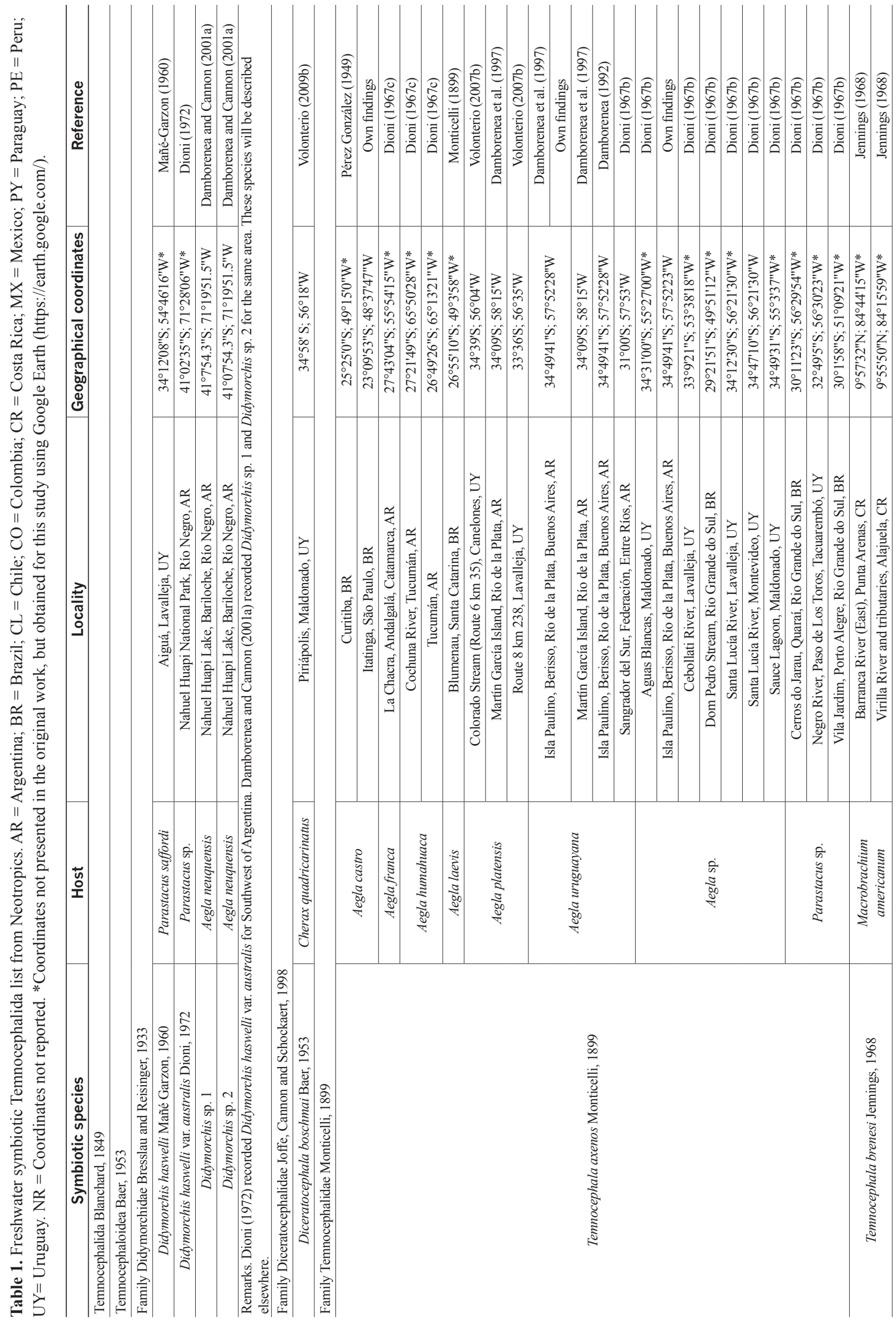




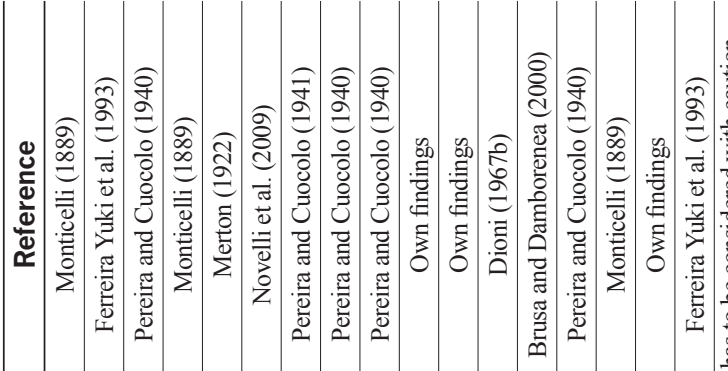

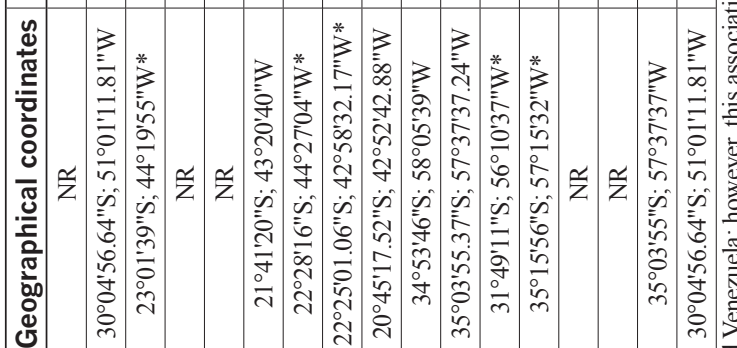

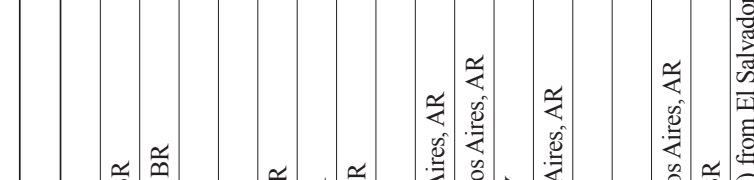

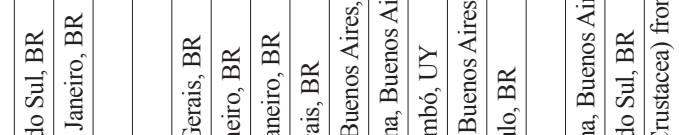

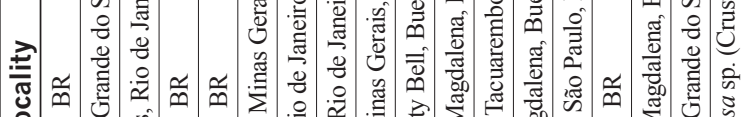

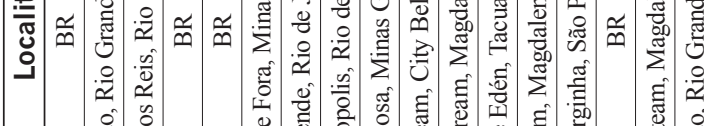

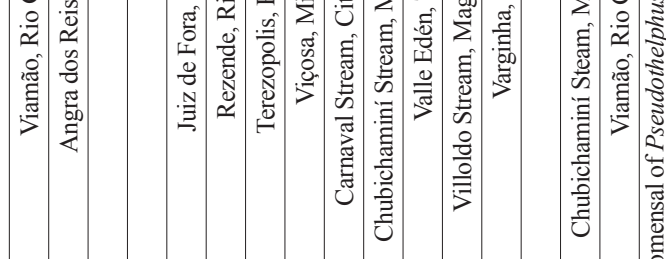

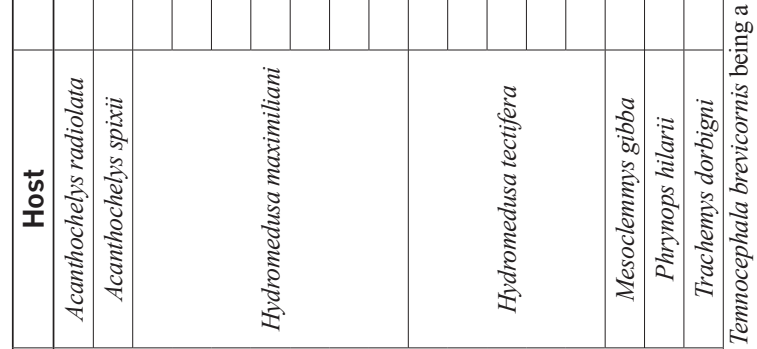

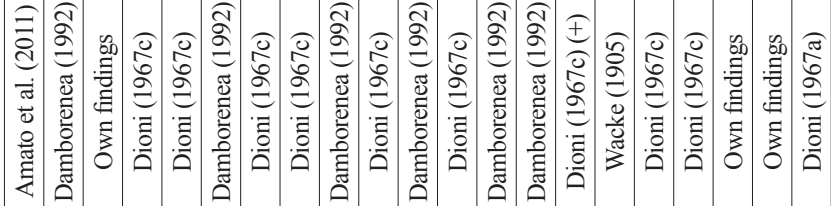

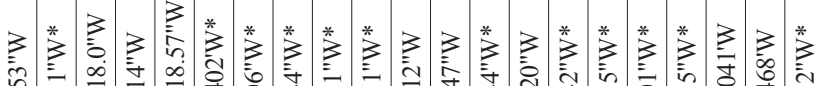

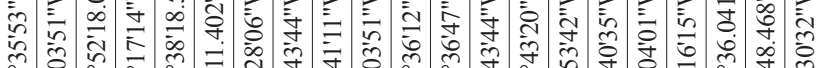
子ُ

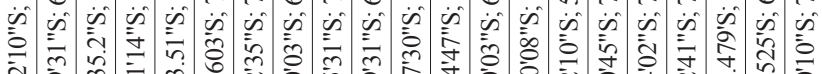

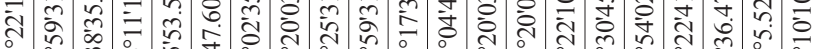

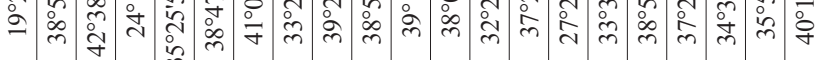

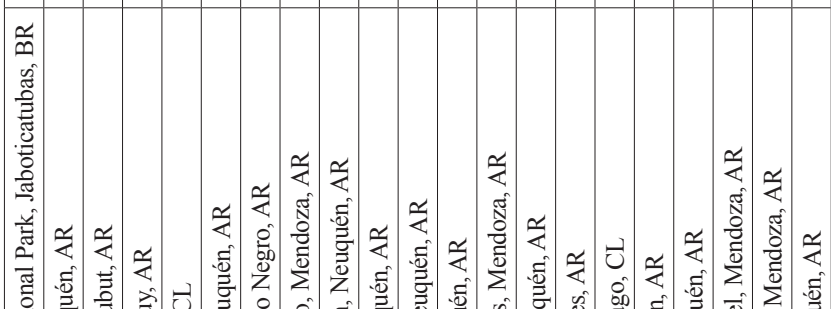

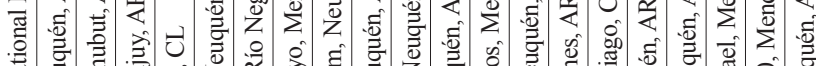

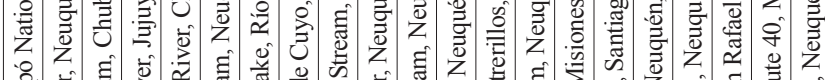

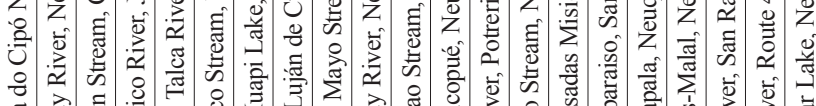

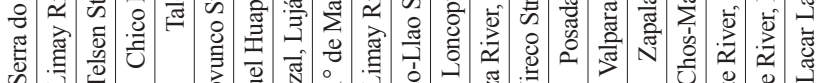

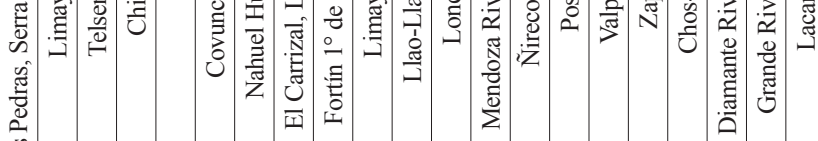

\section{胥} 要

\section{:}

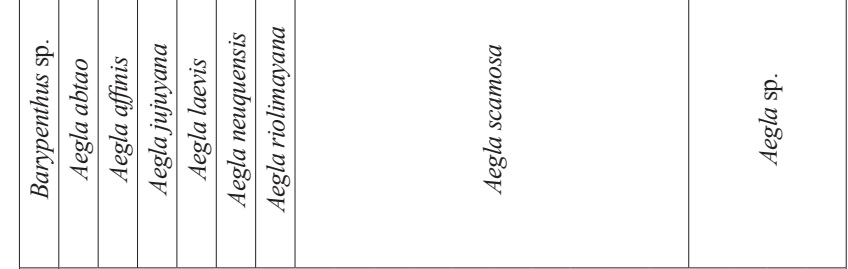

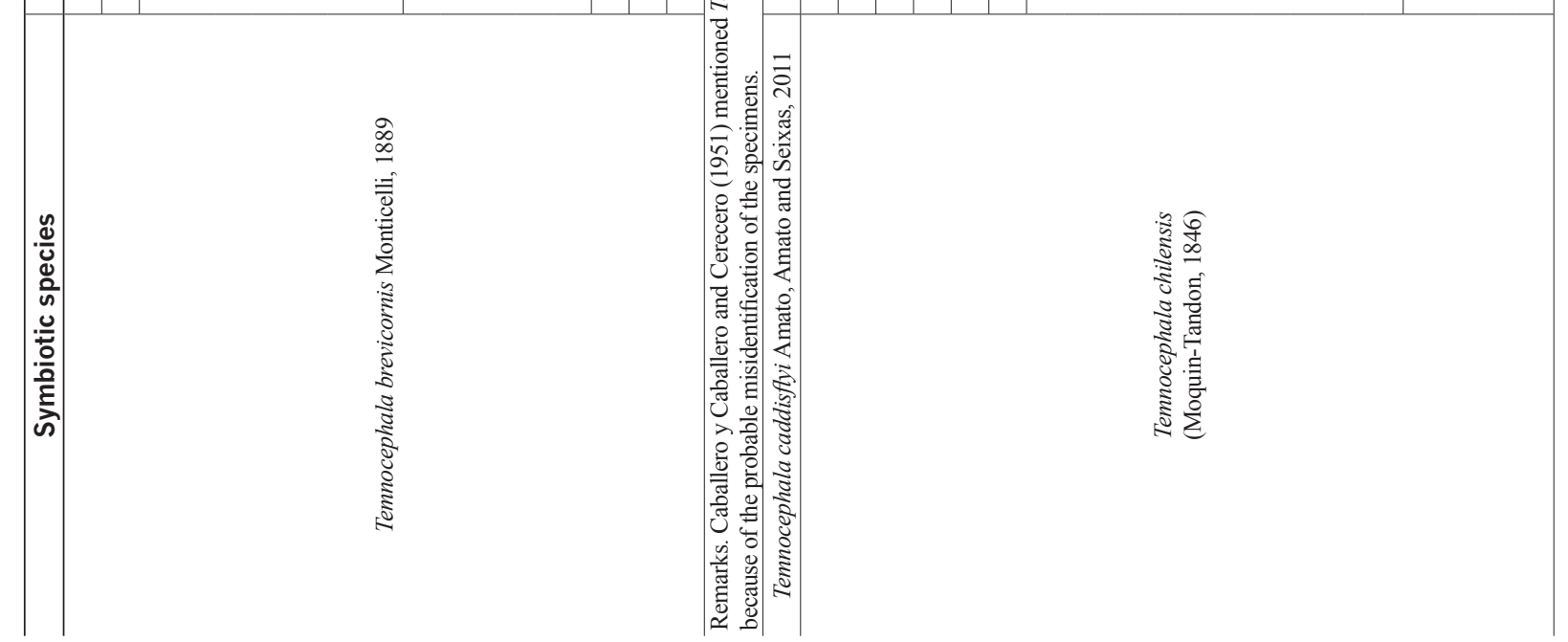




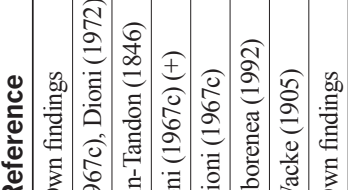

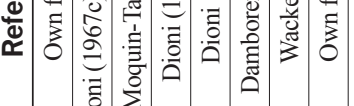 苛}

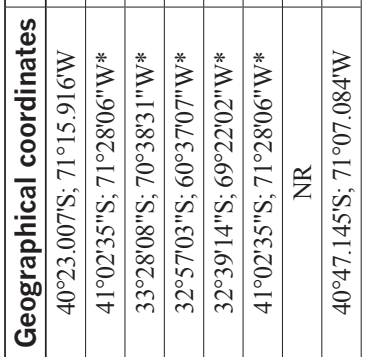

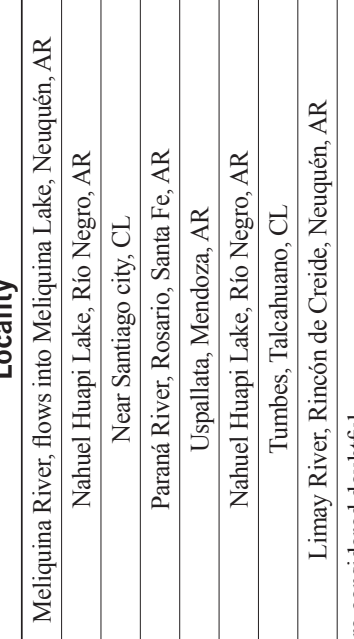

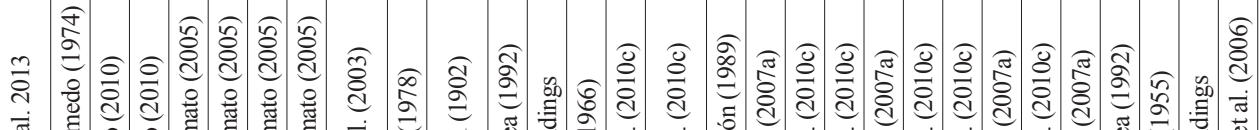

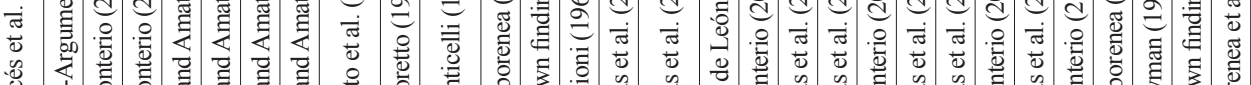

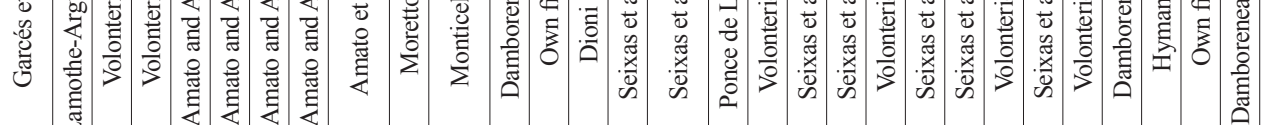

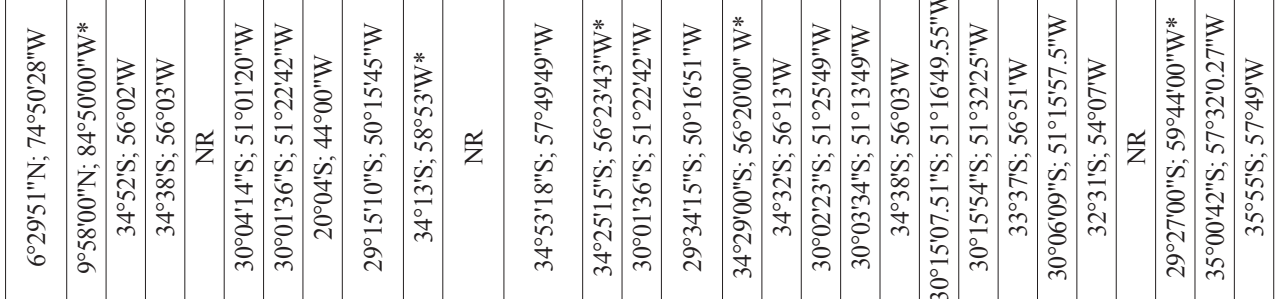

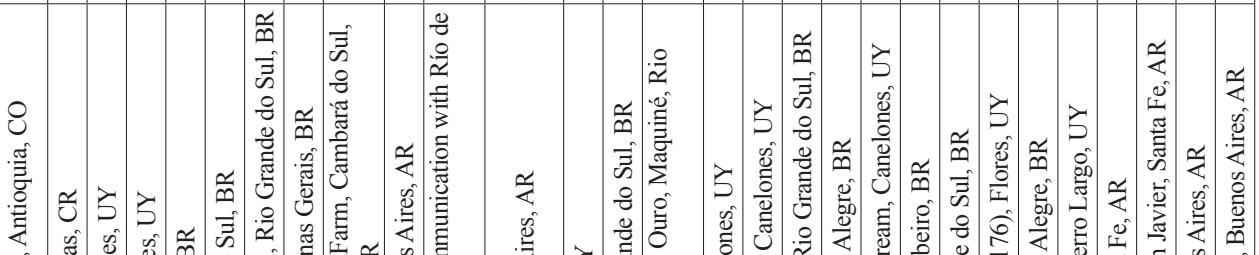

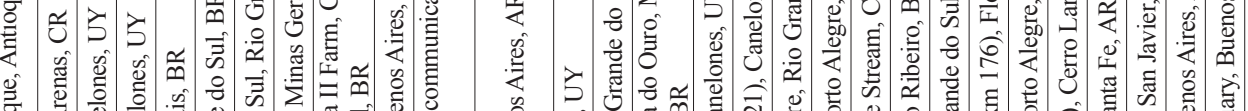

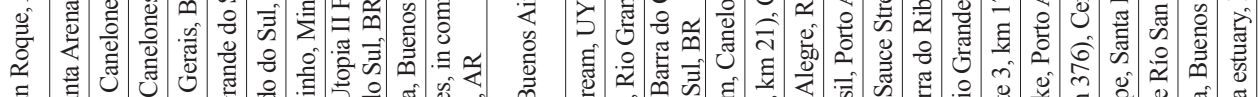

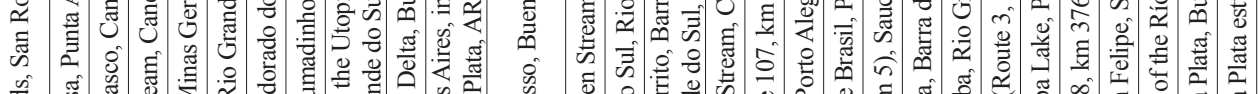

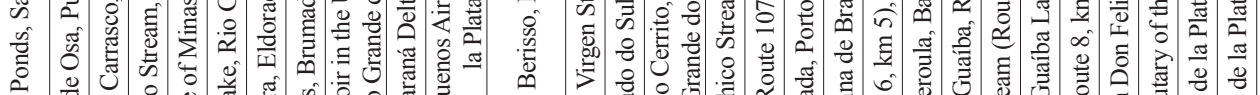

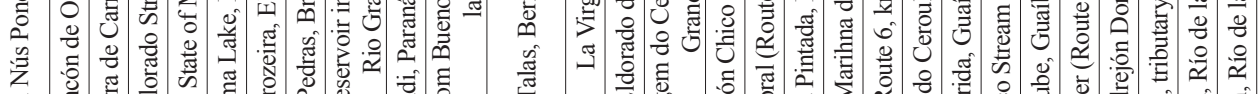

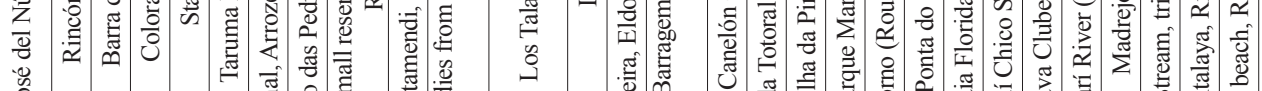

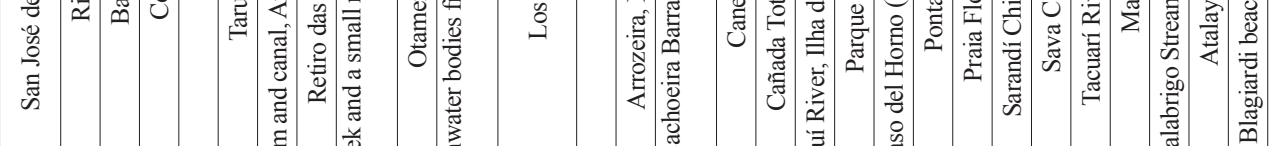

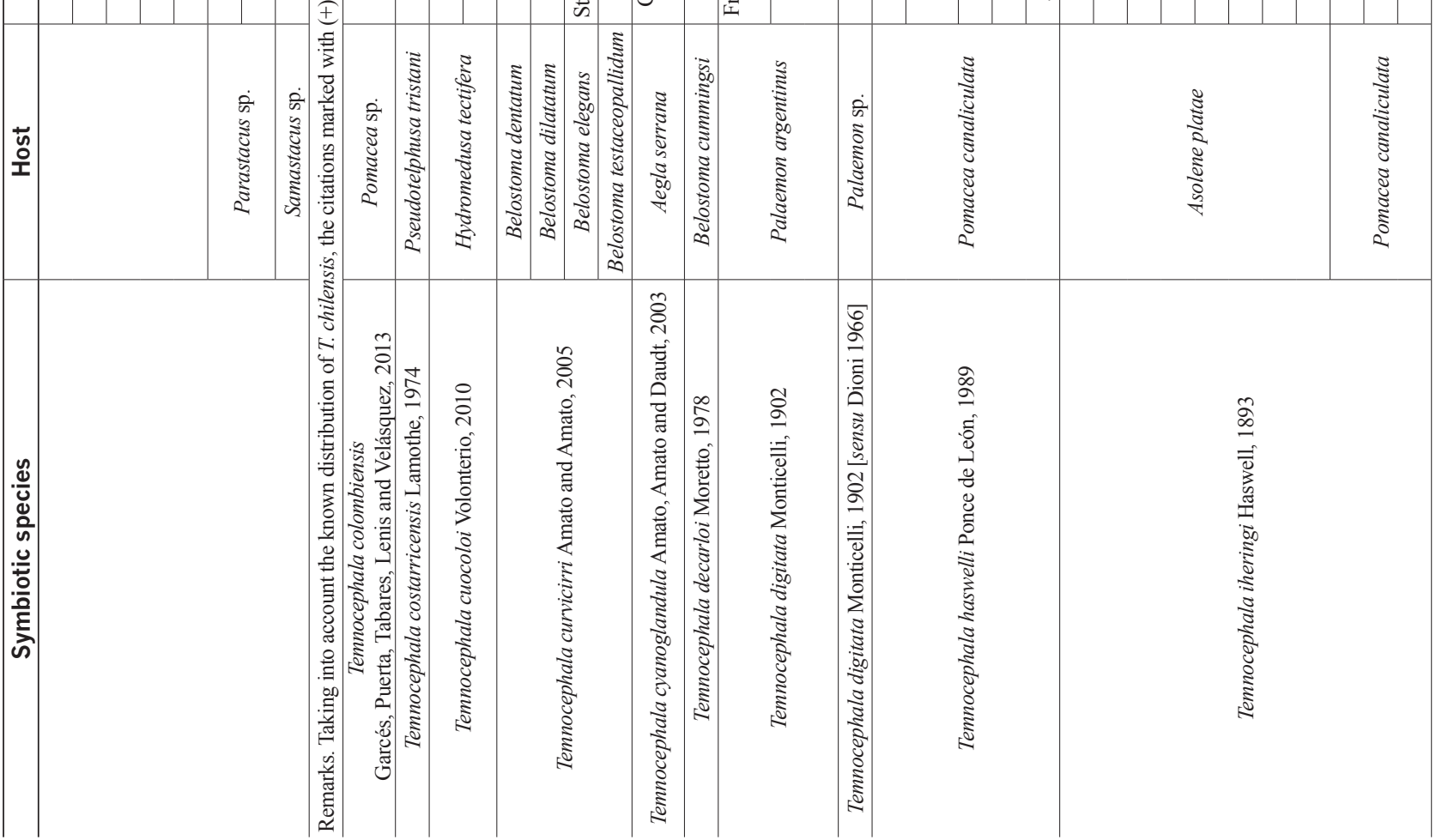




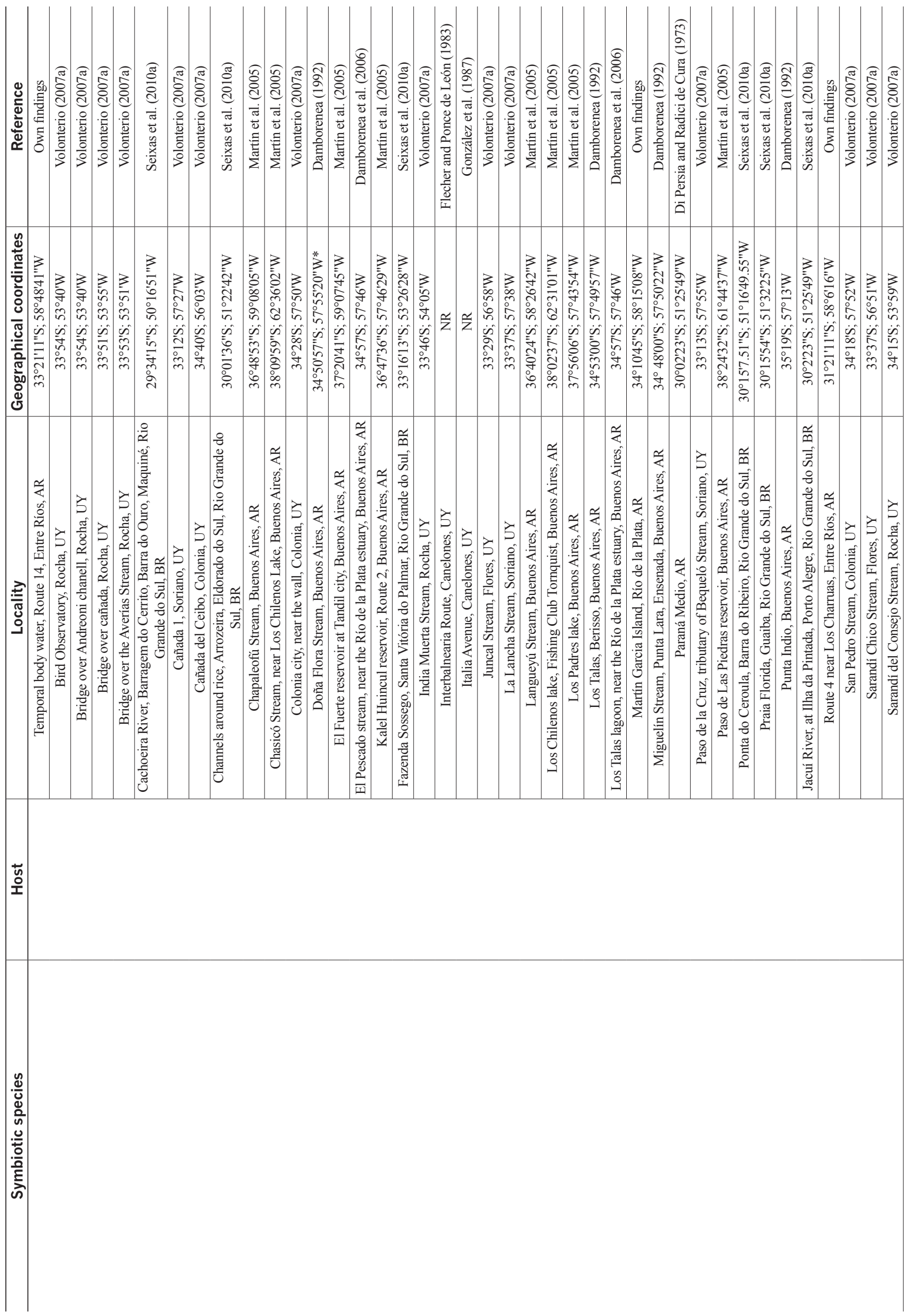




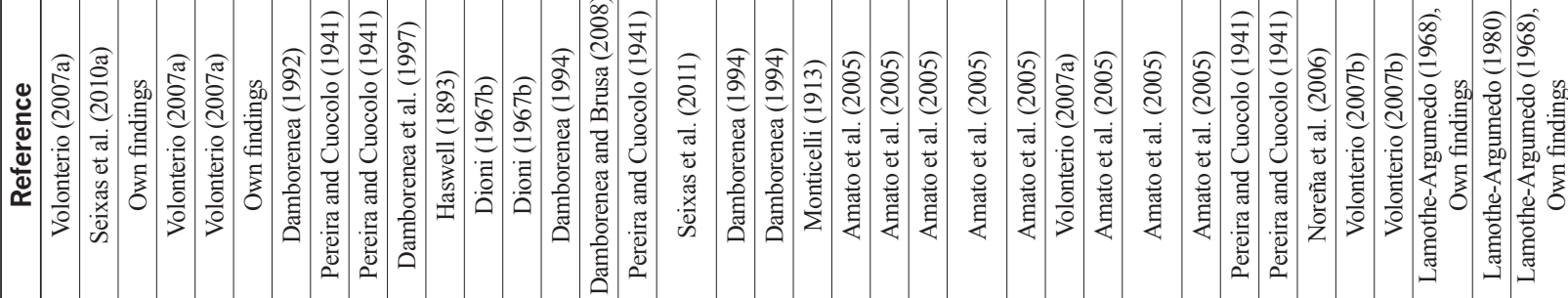

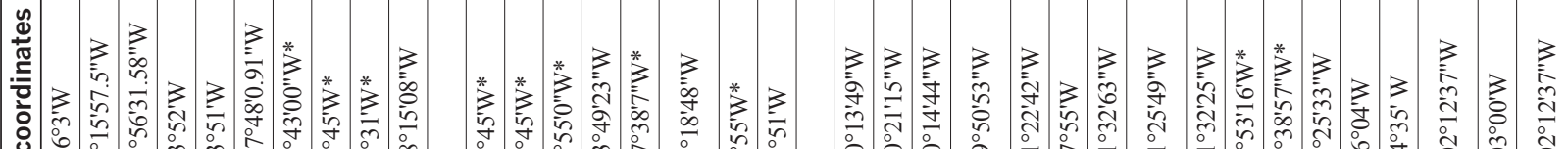

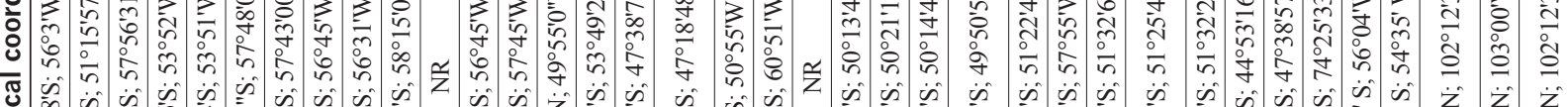

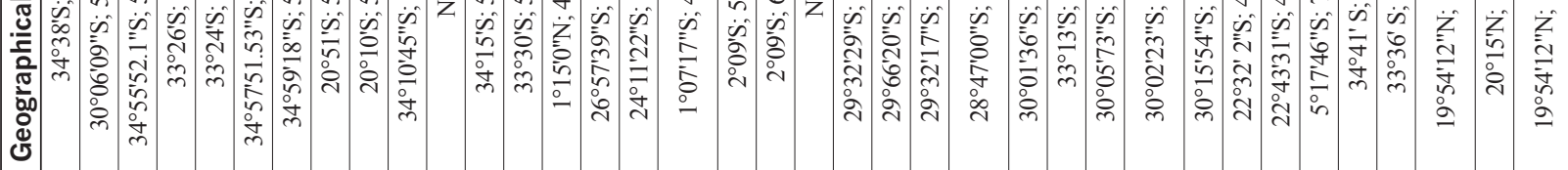

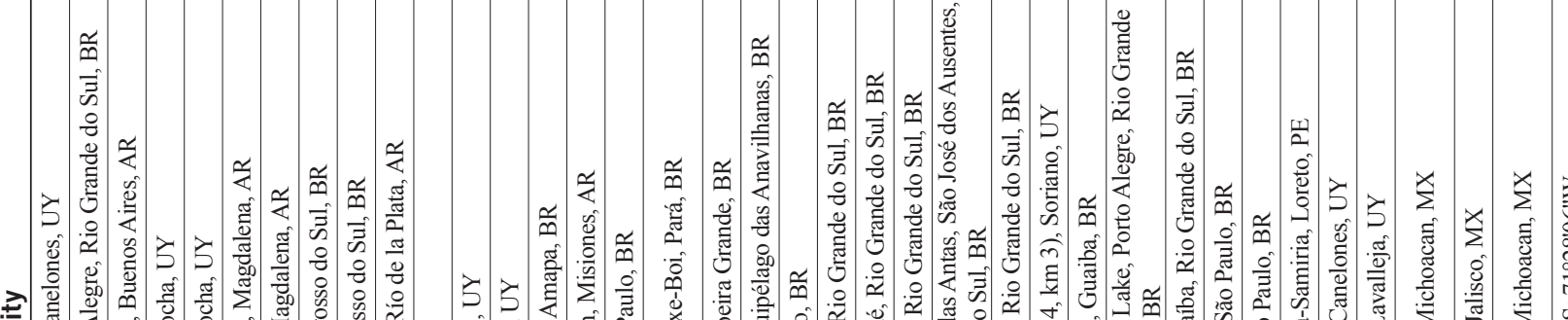

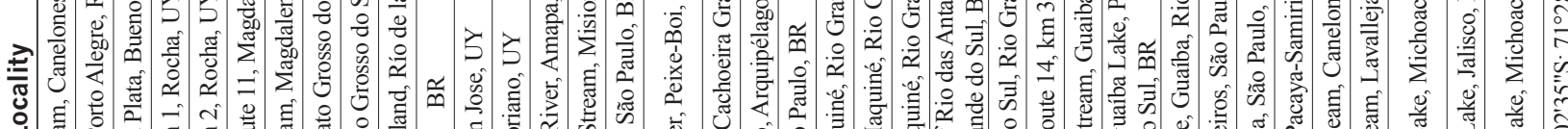

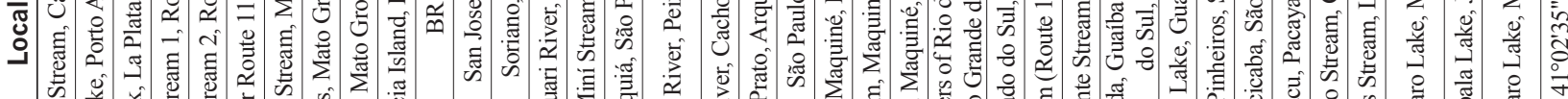

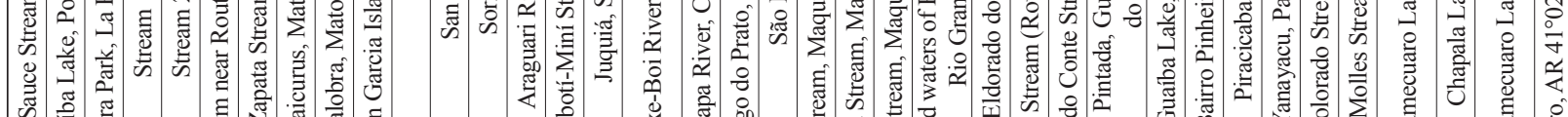

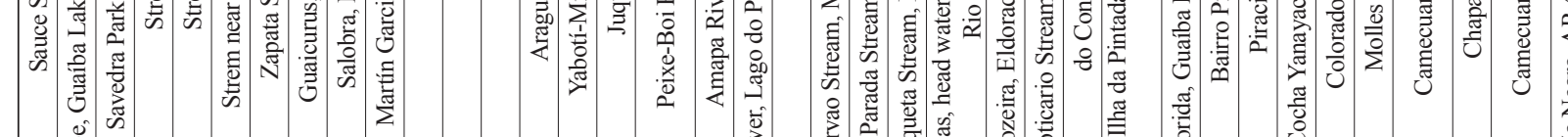

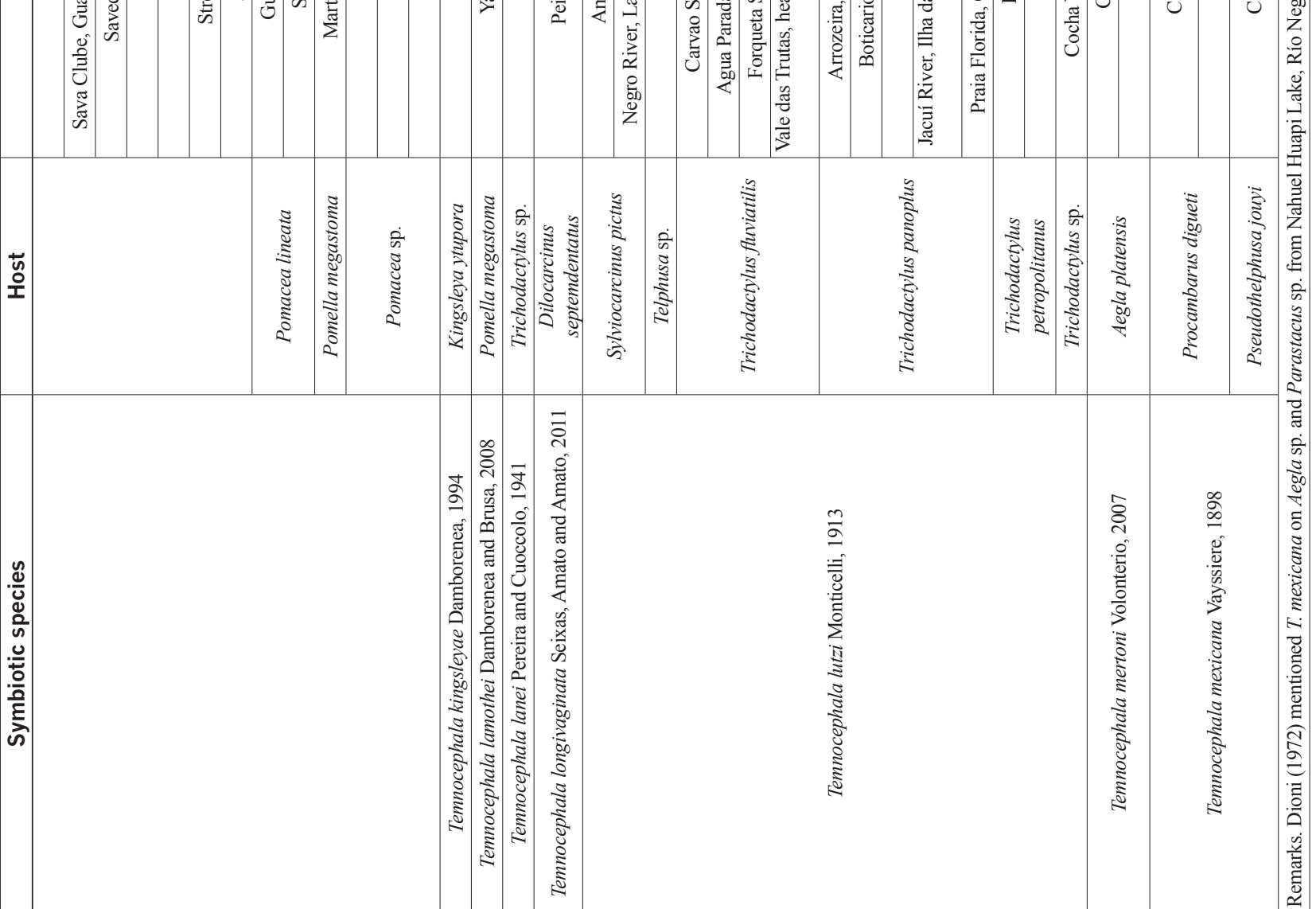




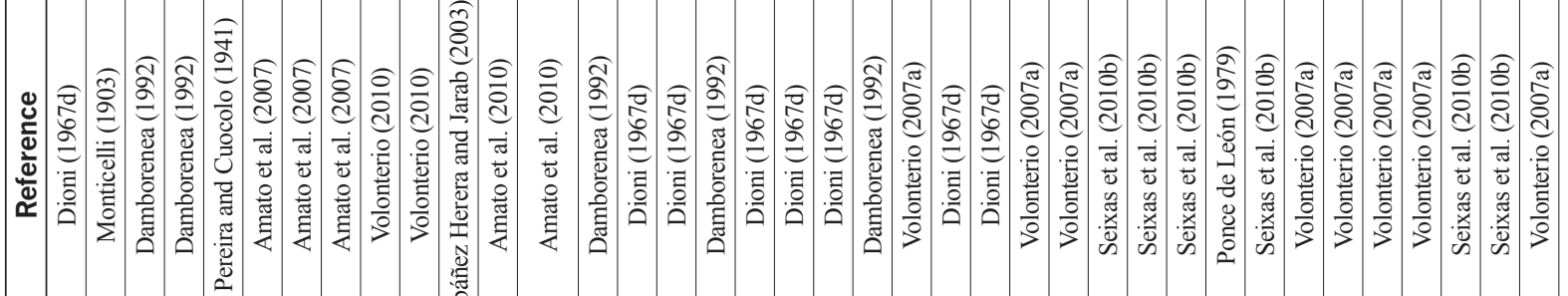

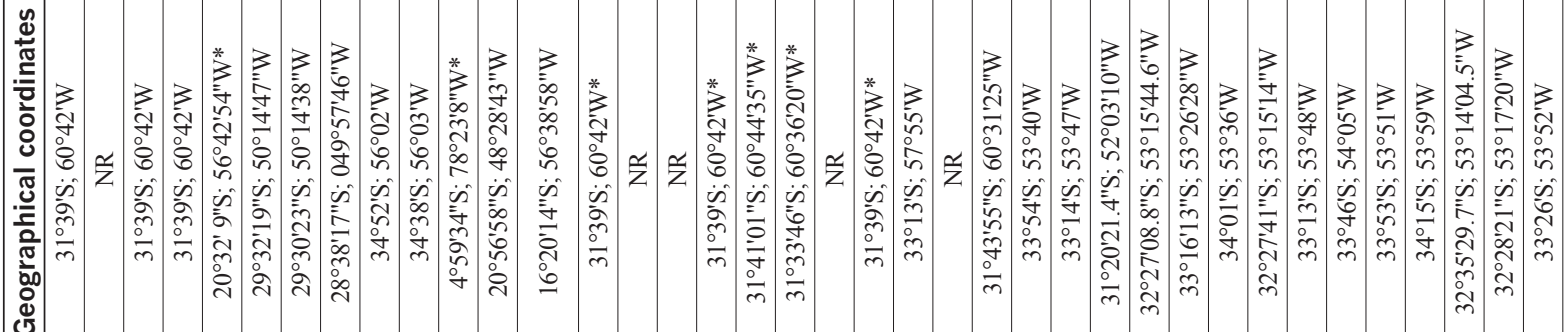

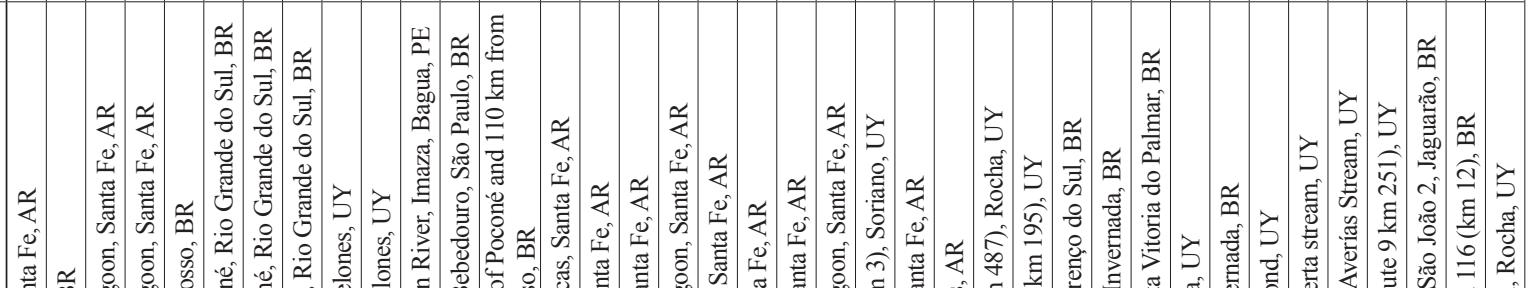

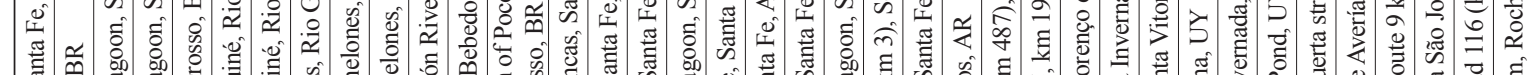

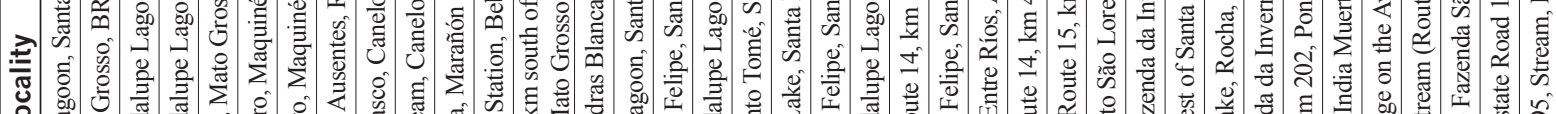

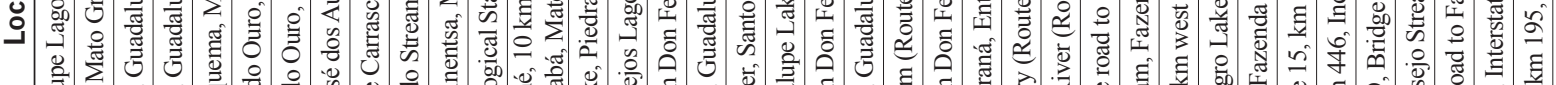

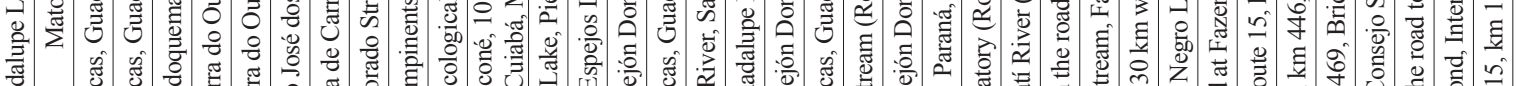

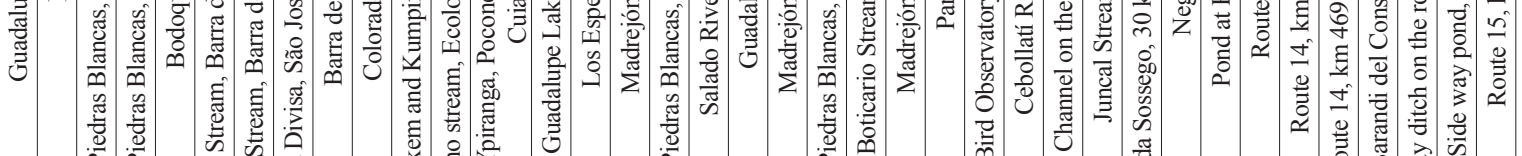

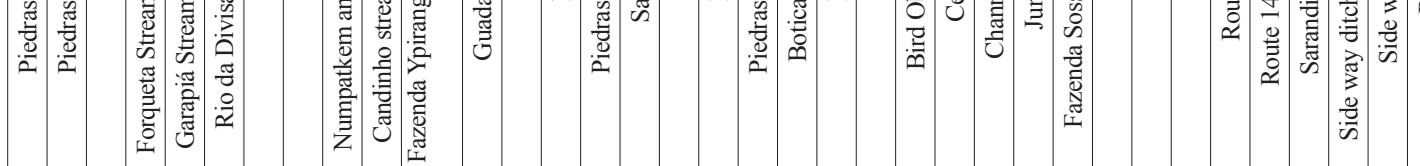

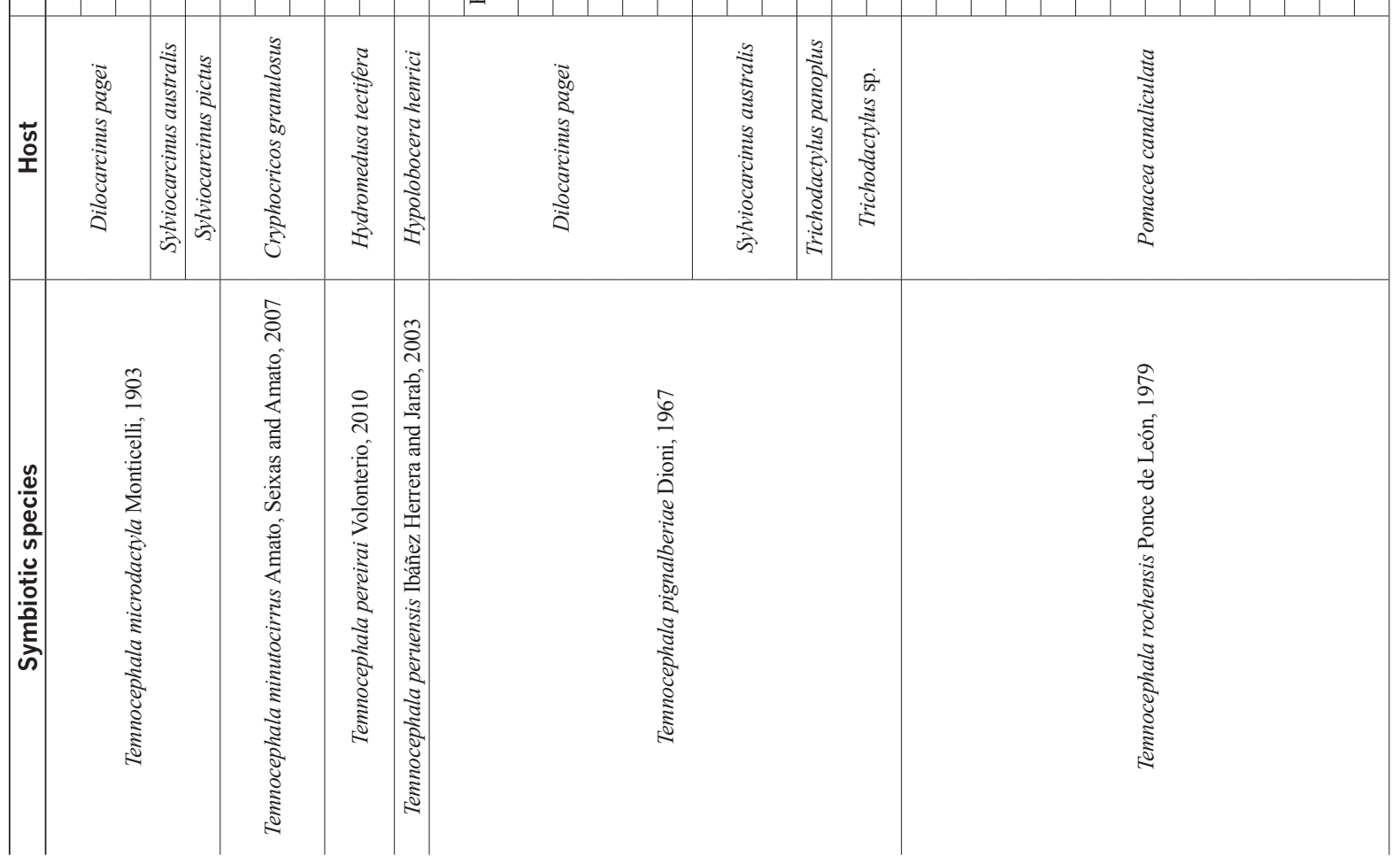




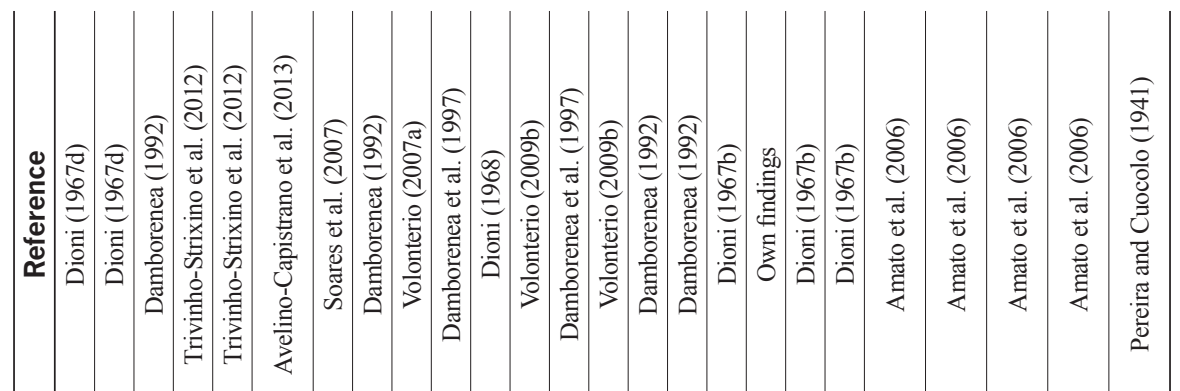

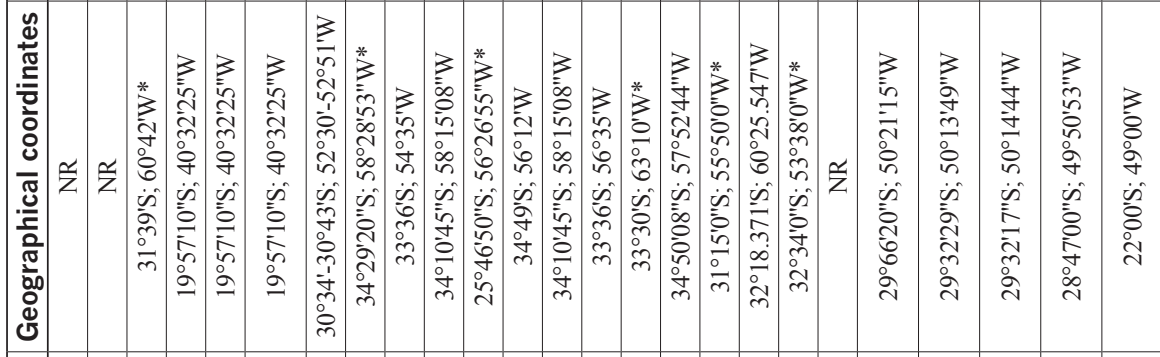

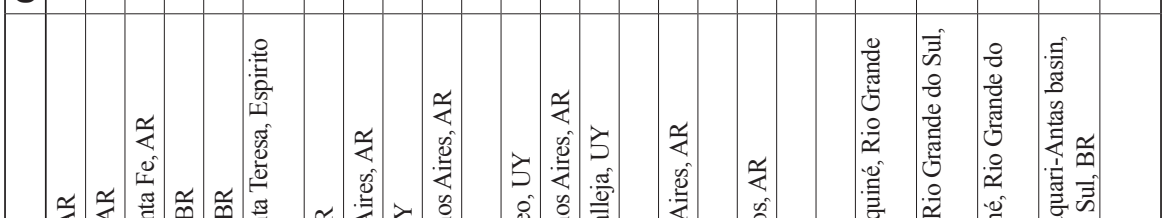

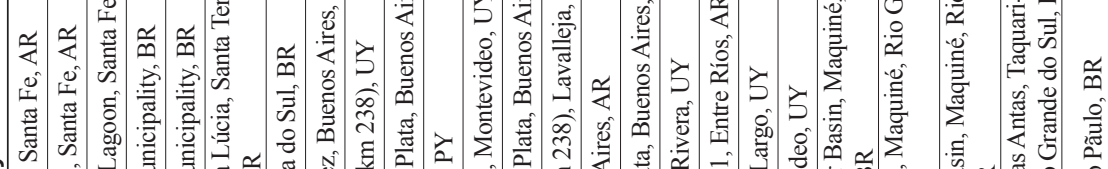

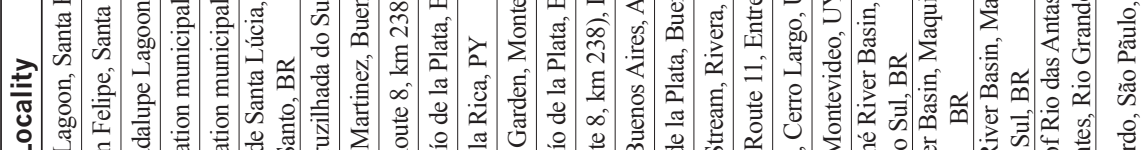

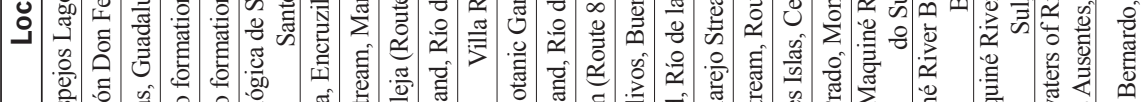

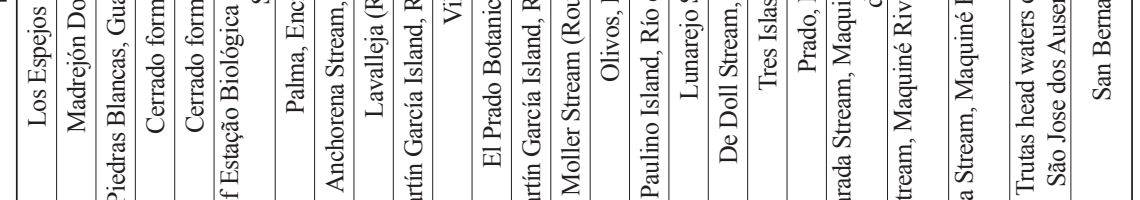

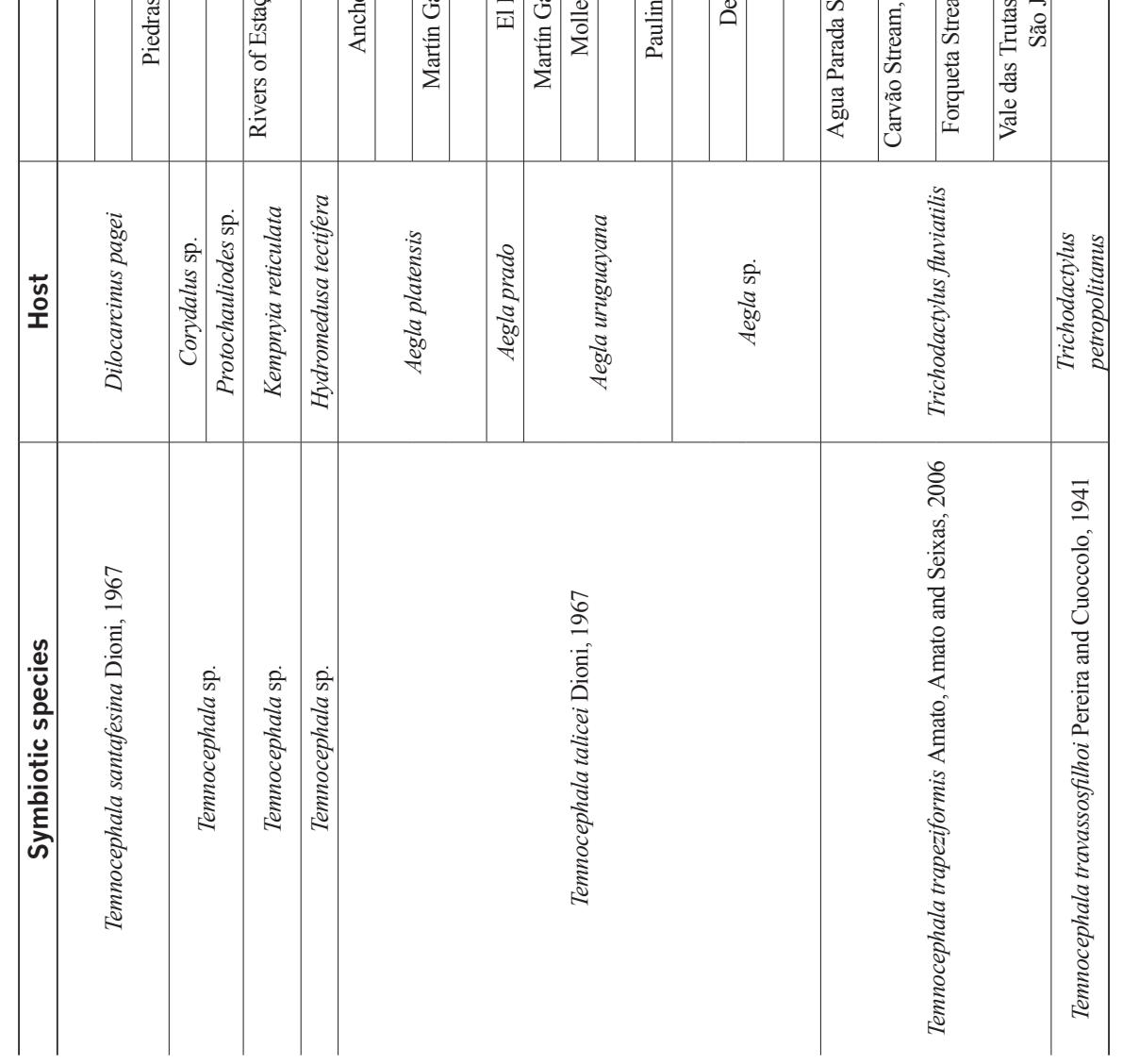




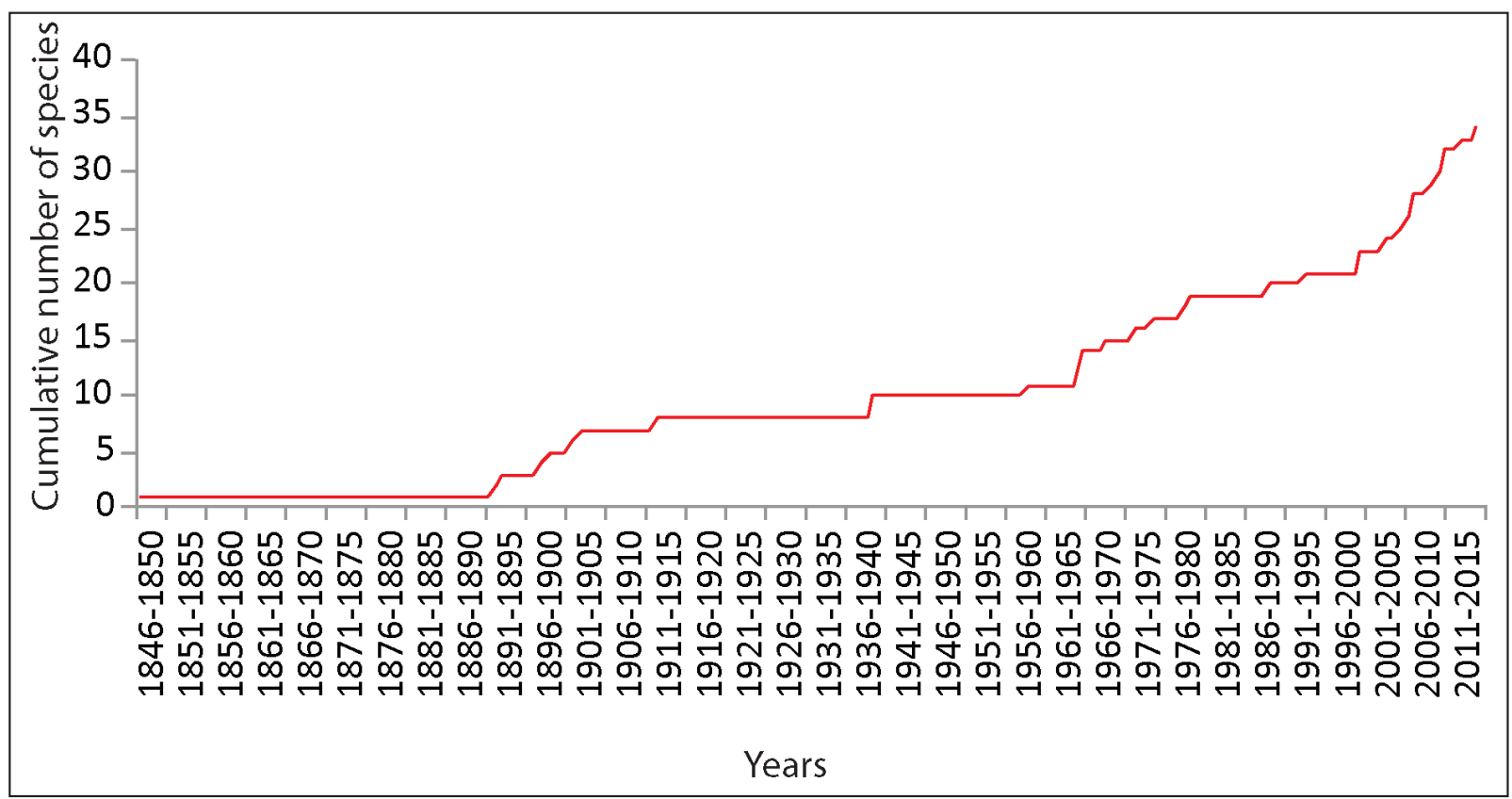

Figure 1. Accumulative species curve for freshwater symbiotic Temnocephala fauna in Neoropics.

species for which more than one locality was recorded, are listed together. Furthermore, a host-symbiont list (See Appendix 1) is taxonomically and alphabetically organized.

The decapods are the most species-rich host group with temnocephalans (27), followed by the insects (5 taxa) and snails ( 5 species). Of the 38 taxa of Temnocephalidae listed in this work, all appear to be specific to particular host groups, while at least only one species of the family Diceratocephalidae have successfully associated with hosts after their anthropogenic introduction, i.e. Diceratocephala boschmai. The most widely distributed species are T. axenos, $T$. chilensis and T. iheringi, which are present in 9 and 10 crab host species and 5 snail host species, along 20, 25 and 49 localities, respectively.

In terms of hosts, Hydromedusa tectifera (a turtle) is the host with the highest temnocephalan species richness with 4 taxa, followed by Aegla neuquensis, A. platensis, Dilocarcinus pagei (decapod crabs) and Pomacea canaliculata (snail), all with 3 species; meanwhile, 49 host taxa show only one record of temnocephalid taxa for one locality.

The species accumulation curve for Neotropic temnocephalans plotted against the total number of species (Figure 1) shows irregular growth over 15 decades of studies in Temnocephalida (each decade divided into two periods of five years). This graph shows that the asymptote has not been reached yet and, if the systematic studies of the group are continued, a significant increase in the number of species in the Neotropical region can be expected. This graphic also reflects two important periods of research. The first shows the initial prospecting for temnocephalid species in the Neotropical region, between 1890 and the beginnings of the 20th century. The second period, beginning around 1970, shows an increase in the research on temnocephalans from different host species, with some stationary periods.

\section{Discussion}

The genus Temnocephala is an endemic component of the Neotropical region (Damborenea and Cannon 2001a). At the moment, it includes 35 taxa, of which 14 (40\%) are considered microendemic (only one record for locality) (Table 1). In total, 57 host taxa are associated with one or more temnocephalan taxa, which belong to seven orders and 14 families within four classes. It is worth pointing out that each major group of hosts is characterized by a particular assemblage of temnocephalan species, with host specificity at family level. For example, 17 taxa of Temnocephala are associated with three families of freshwater crab hosts (Aeglidae, Pseudothelphusidae and Trichodactylidae), while five Temnocephala species are associated with 8 taxa of freshwater shrimps included in three families (Cambariade, Palaemonidae and Parastacidae). Information about the natural history of this endemic genus is key to understanding the role of different factors that shaped its diversification patterns across several hydrological basins in the Neotropics and the possible implications of codivergence with host groups (see below) (e.g. Thompson 2005, Martínez-Aquino et al. 2014b).

In this inventory, only Diceratocephala boschmai was detected as an introduced species because of translocation together with their crustacean hosts, the invasive redclaw Cherax quadricarinatus in Uruguay (Volonterio 2009a), due to human activities such as aquaculture and breeding of ornamental species (Lodge et al. 2012, Saoud and Ghanawi 2013). According to several authors, $D$. boschmai causes a detrimental economic impact because of an aesthetic effect of the eggs on the body surface of the C. quadricarinatus (Herbert 1987, Volonterio 2009a). However, it is more important to mention the detrimental biological and ecological impact of these introduced 


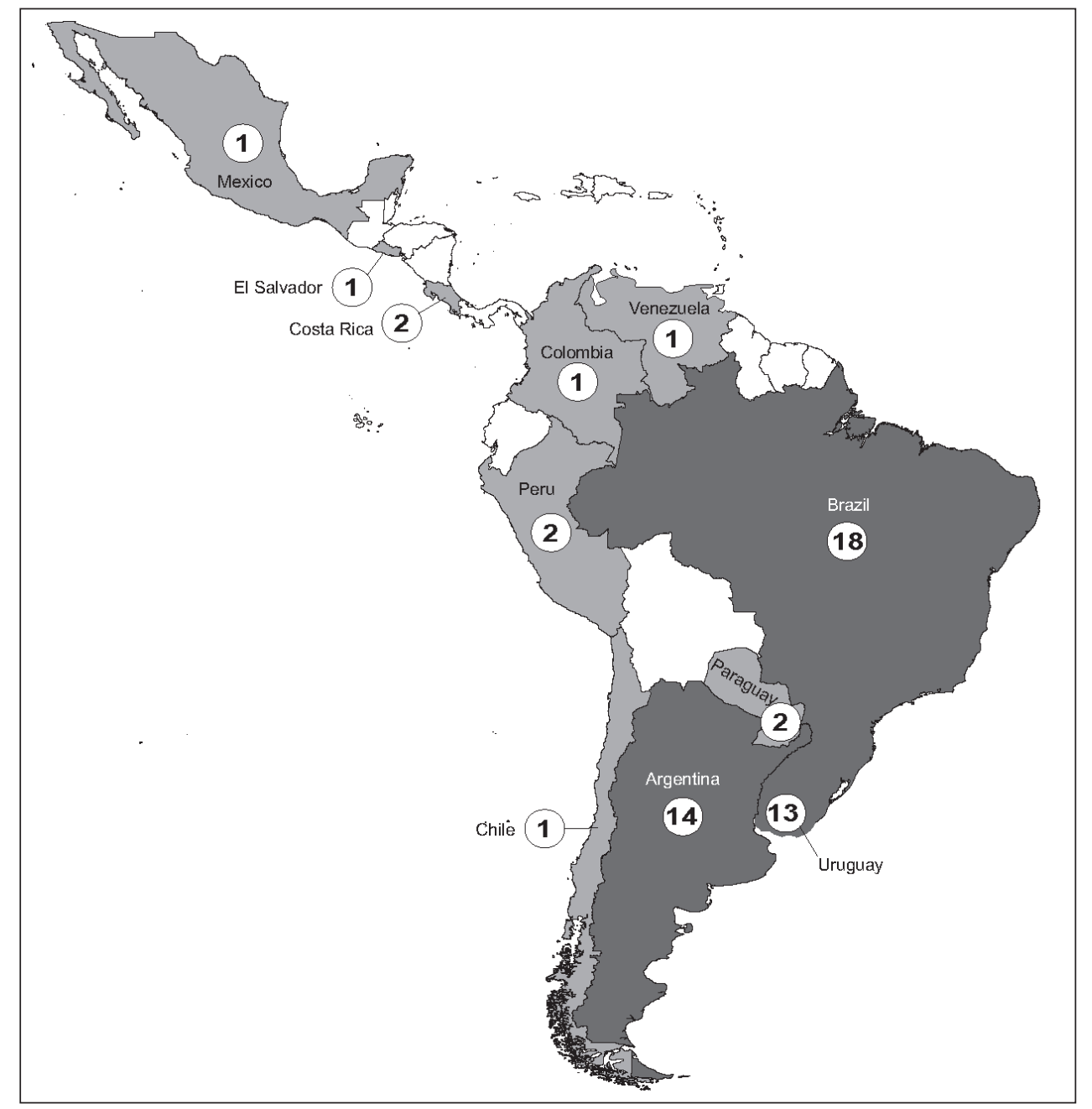

Figure 2. Map of Latin America indicating the countries where freshwater invertebrate and vertebrate hosts, of four classes, have been studied for neotropic symbiotic temnocephalans. Countries with major to 10 species records in dark grey and minor to 2 in low grey. The numbers in circles indicate the total temnocephalan taxa recorded. Map produced by http://www.naturalearthdata.com/, and modified in DIVA-GIS 7.5 (Hijmans et al. 2012) (freely available throught www.diva-gis.org).

species (e.g. Ahyong and Yeo 2007, Larson and Olden 2012). To date, the values of ecological infection parameters (e.g. prevalence and abundance; see Bush et al. 1997) are unknown not only locally but globally. These parameters are required to measure the effect of this symbiotic association - both introduced species, C. quadricarinatus and D. boschmai - to detect the extent of the spread of D. boschmai to other crustacean taxa, especially endemic crabs in their natural ecosystems (Jones and Lester 1993, Chivavaya 2013, du Preez and Smit 2013). Furthermore, the introduced populations of D. boschmai in natural hydrological systems in Uruguay represent a serious problem of displacement to the endemic populations of Neotropical Temnocephala species because of interspecific competition between symbiotic organisms (Gelder 1999, Sicard et al. 2006, Witte et al. 2008, Tsuchida et al. 2011, Ohtaka et al. 2012). In this context, the data generated in this checklist can be used to support conservation strategies for freshwater biodiversity (Cardoso et al. 2011a, b, Stendera et al. 2012, Collen et al. 2013).
One hundred sixty eight years have passed since the first description and record of a temnocephalan from the Neotropics (Damborenea and Cannon 2001a), and, currently, \pm 236 records of temnocephalans have been published. However, considering the number of described species and the time passed, it can be stated that most of the diversity of Temnocephala remains yet to be described. There is also a significant number of potential hosts that have not been studied with regards to symbiotic temnocephalans. On the other hand, Schoackaert et al. (2008) mentioned that the few species recorded in South America were mostly recorded up to about 1970. Based on the species accumulation curve (Figure 1), this study shows clearly the increase in knowledge about the biodiversity of the temnocephalan fauna in recent times, but based on all of the information compiled for Neotropic temnocephalans, we show the necessity to continue inventory work. The Neotropic temnocephalan fauna contains $31 \%$ of Temnocephalida taxa described at the moment, representing 37 taxa allocated to two genera. 
This checklist presents data on almost all the extant species of temnocephalans along their distributional ranges in 11 Neotropical countries, which represents $35 \%$ of the total political territories (i.e. countries) in the Neotropics (Figure 2). Argentina, Brazil and Uruguay are the countries with the most records of temnocephalans and with the most endemic species of Temnocephala, which are represented by 6,9 and 4 species, respectively, while Colombia, Costa Rica, Mexico and Peru hold 1, 2, 1 and 1 endemic species, respectively. The relatively high number of records in Argentina, Brazil and Uruguay can imply that in these countries there are more research groups working with turbellarians compared to other Neotropical countries (e.g. Damborenea and Brusa 2008, Volonterio 2010, Amato et al. 2011). Therefore, the values of endemism for these particular countries are subjective - a function of the research effort - and it is probable that the endemism may be increased/decreased in future studies from different Neotropical countries. With regards to its exclusively Neotropical distribution, morphological evidence (mosaic syncytial plates) (e.g. Cannon and Joffe 2001, Damborena and Cannon 2001b), plus the recorded host specificities shown in this study (Appendix 1), allow for the inference that the biological radiation of Temnocephala may be the result of a complex combination of ancestral allopatric speciation processes (as a result of the separation of South America and Australia), plus the diversification of their host groups (e.g. Parastacidae) in South (and subsequent radiation in Central) America. For example, the species of Temnocephala associated with mollusks appear to be a morphologically homogeneous group with a phylogenetic structure (Volonterio 2007a, Damborenea and Brusa 2008). On the other hand, the almost exclusive distribution in the Southern Hemisphere of the family to which Temnocephala belongs (Temnocephalidae) is noteworthy and alludes to a Gondwanian origin (Gelder 1999, Cannon and Joffe 2001). However, a reliable molecular clock of the Temnocephalida is required to support or reject this hypothesis. Future studies combining research programs in integrative taxonomy (Schlick-Steiner et al. 2010, Ceccarelli et al. 2012, Fujita et al. 2012) with approaches of historical association (e.g. genes, organism and areas; see Page and Charleston 1998) will decipher the evolutionary history of Temnocephala.

At least 60 papers have been published dealing with the records of Neotropic symbiotic temnocephalans; however, the scarcity of studies in many countries is clear, and needs to be rectified. For example, some countries comprising complex geographic areas (i.e. Mexican Transition Zone, South American Transition Zone) only have one record of these turbellarians, and the diversity of the four major hosts groups is also unknown (Martínez-Aquino et al. 2014a). Therefore, we contend that future survey work should be strategic, aimed at enhancing the biodiversity inventory, combining identification of the host spectrum with choice of appropriate drainages based on biogeographic, faunistic, and hydro- logic data and on lessons from other freshwater symbiotic Platyhelminthes (e.g. Pérez-Ponce de León and Choudhury 2010, Martínez-Aquino et al. 2014c).

\section{Acknowledgements}

We thank F.S. Ceccarelli, R. Pérez-Rodríguez, L. Alcalde and L. Negrete for their help during field work. L. García-Prieto for providing literature and specimens for morphological comparison deposited at the CNHE. J. Vigliano Relva help to obtained geographical coordinates. We thank Sean M. Rovito for help with language editing and two reviewers for their constructive criticisms. A.M-A. is currently supported by a postdoctoral grant from CONACyT, Mexico (No. 207983). This study was supported by grants PIP CONICET 0390 and FCNyM-UNLP N11/728 to C.D. and PIP CONICET 11220120100635 CO F.B.

\section{References}

Amato JFR, Amato SB (2005) New species of Temnocephala Blanchard (Platyhelminthes, Temnocephalida) ectosymbiont on giant water bugs, Belostoma spp. (Hemiptera, Belostomatidae) from southern Brazil. Revista Brasileira de Zoologia 22: 107-118. doi: 10.1590/ S0101-81752005000100014

Amato JFR, Amato SB, Daudt LCC (2003) New species of Temnocephala Blanchard (Platyhelminthes, Temnocephalida) ectosymbiont on Aegla serrana Buckup and Rossi (Crustacea, Anomura) from southern Brazil. Revista Brasileira de Zoologia 20: 493-500. doi: 10.1590/S0101-81752003000300021

Amato JFR, Amato SB, Seixas SA (2005) Temnocephala lutzi Monticelli (Platyhelminthes, Temnocephalida) ectosymbiont on two species of Trichodactylus Latreille (Crustacea, Decapoda, Trichodactylidae) from southern Brazil. Revista Brasileira de Zoologia 22: 1085-1094. doi: 10.1590/S0101-81752005000400038

Amato JFR, Amato SB, Seixas SA (2006) A new species of Temnocephala Blanchard (Platyhelminthes, Temnocephalida) ectosymbiont on Trichodactylus fluviatilis Latreille (Crustacea, Decapoda, Trichodactylidae) from southern Brazil. Revista Brasileira de Zoologia 23: 796-806. doi: 10.1590/S0101-81752006000300026

Amato JFR, Seixas SA, Amato SB (2007) A new species of Temnocephala Blanchard (Platyhelminthes, Temnocephalida) ectosymbiont on creeping water bugs, Cryphocricos granulosus De Carlo (Hemiptera, Naucoridae) from southern Brazil. Revista Brasileira de Zoologia 24: 1043-1051. doi: 10.1590/S0101-81752007000400022

Amato JFR, Seixas SA, Amato SB (2010) Temnocephala pignalberiae Dioni, 1967 (Platyhelminthes, Temnocephalida) from two allopatric populations of Dilocarcinus pagei Stimpson, 1861 (Crustacea, Decapoda) - first record for Brazil. Zootaxa 2613: 15-28.

Amato JFR, Amato SB, Seixas SA, Vidigal THDA, Andrade CDP (2011) Trichoptera - the newest insect order host of temnocephalans (Platyhelminthes, Temnocephalida) and the description of a new species of Temnocephala from Brazil. Zootaxa 2975: 47-58.

Ahyong ST, Yeo DCJ (2007) Feral populations of the australian redclaw crayfish (Cherax quadricarinatus von Martens) in water 
supply catchments of Singapore. Biological Invasions 9: 943-946. doi: 10.1007/s10530-007-9094-0

Avelino-Capistrano F, Barbosa LS, Cunha AM (2013) Occurrence of Temnocephala (Platyhelminthes: Temnocephalida) in immatures of Kempnyia reticulata (Enderlein) (Insecta: Plecoptera: Perlidae). EntomoBrasilis 6: 91-93. doi: 10.12741/ebrasilis.v6i1.226

Brusa F, Damborenea MC (2000) First report of Temnocephala brevicornis Monticelli, 1889 (Temnocephalidae: Platyhelminthes) in Argentina. Memoirs Instituto Oswaldo Cruz 95: 81-82. doi: 10.1590/ S0074-02762000000100012

Bush AO, Lafferty KD, Lotz LL, Shostak AW (1997) Parasitology meets ecology on its own terms: Margolis et al., revisited. Journal of Parasitology 83 (4): 575-583. doi: 10.2307/3284227

Caballero y Caballero E, Cerecero DMC (1951) Presencia de Temnocephala brevicornis Monticelli, 1889 en crustáceos venezolanos. Revista de Medicina Veterinaria y Parasitología 10: 111-117.

Cannon LRG, Joffe BI (2001) The Temnocephalida. In: Littlewood DTJ, Bray RA (Eds) Interrelationships of the Platyhelminthes. Taylor \& Francis, London, 83-91.

Cardoso P, Borges PAV, Triantis KA, Ferrández MA, Martín JL (2011a) Adapting the IUCN Red List criteria for invertebrates. Biological Conservation 144: 2432-2440. doi: 10.1016/j.biocon.2011.06.020

Cardoso P, Erwin TL, Borges PAV, New TR (2011b) The seven impediments in invertebrate conservation and how to overcome them. Biological Conservation 144: 2647-2655. doi: 10.1016/j.biocon.2011.07.024

Ceccarelli FS, Sharkey MJ, Zaldívar-Riverón A (2012) Species identification in the taxonomically neglected, highly diverse, neotropical parasitoid wasp genus Notiospathius (Braconidae: Doryctinae) based on an integrative molecular and morphological approach. Molecular Phylogenetics and Evolution 62: 485-495. doi: 10.1016/j.ympev.2011.10.018

Collen B, Whitton F, Dyer EE, Baillie JEM, Cumberlidge N, Darwall WRT, Pollock C, Richman NI, Soulsby A-M, Böhm M (2013) Global patterns of freshwater species diversity, threat and endemism. Global Ecology and Biogeography 23: 40-51. doi: 10.1111/geb.12096

Cowie RH, Thiengo C (2003) The Apple snails of the Americas (Mollusca: Gastropoda: Ampullariidae: Asolene, Felipponea, Marisa, Pomacea, Pomella): a nomenclatural and type catalog. Malacologia 45: 4-100.

Chivavaya I (2013) Prevalence and abundance of an ectocommensal Temnocephalid on the Australian red claw crayfish (Cherax quadricarinatus, von Martens 1868) in the Sanyati Basin, Lake Kariba, Zimbabwe. Ms. Sc. Thesis, Department of Biological Sciences, Bindura University of Science Education, Zimbabwe.

Damborenea MC (1992) Especies de Temnocephala (Platyhelminthes, Temnocephalidea) de crustáceos y moluscos de la Argentina. Iheringia, Série Zoologia 72: 3-21.

Damborenea MC (1994) Temnocéfalos neotropicales: Temnocephala kingsleyae sp. n. y T. lutzi Monticelli, 1913 (Platyhelminthes, Temnocephalidea) comensales de crustáceos de Brasil. Iheringia, Série Zoologia 77: 99-105.

Damborenea MC (1998) Distribution patterns of Temnocephalids comensal with Crustacea and Mollusca from Argentina. Hydrobiologia 383: 269-274. doi: 10.1023/A:1003430131129

Damborenea MC, Brusa F (2008) A new species of Temnocephala (Platyhelminthes, Temnocephalida) commensal of Pomella megastoma (Mollusca, Ampullariidae) from Misiones, Argentina. Revista Mexicana de Biodiversidad 79: 1-7.

Damborenea MC, Brusa F (2009) A new species of Temnosewellia (Platyhelminthes, Temnocephalida) ectosymbiont on Villopotamon thaii (Crustacea, Decapoda, Potamidae) from Vietnam. Zoosystema 31: 321-332. doi: 10.5252/z2009n2a5

Damborenea MC, Cannon LRG (2001a) On neotropical Temnocephala (Platyhelminthes). Journal of Natural History 35: 1103-1118. doi: 10.1080/00222930152434454

Damborenea MC, Cannon LRG (2001b) The mosaic of the epidermal syncytia in Didymorchis sp. (Didymorchidae, Temnocephalida) from South America. Belgian Journal of Zoology 131: 167-171.

Damborenea MC, Brusa F, Paola A (2006) Variation in worm assemblages associated with Pomacea canaliculata (Caenogastropoda, Ampullariidae) in sites near the Río de la Plata estuary, Argentina. Biocell 30: 457-468.

Damborenea MC, Cesar II, Armendariz L (1997) Especies de Temnocephala (Platyhelminthes: Temnocephalidae) de la Isla Martín García, Buenos Aires, Argentina. Neotropica 43: 123-124.

De Grave S, Ashelby CW (2013) A re-appraisal of the systematic status of selected genera in Palaemoninae (Crustacea: Decapoda: Palaemonidae). Zootaxa 3734: 331-344. doi: 10.11646/zootaxa.3734.3.3

Dioni W (1966) Temnocephalas uruguayas. I. Redescripción de Temnocephala digitata Monticelli, 1902 (Turbellaria, Temnocephaloidea). Physis 26: 219-223.

Dioni W (1967a) Temnocephalas argentinas. I. Notas sobre Temnocephala chilensis (Moquin-Tandon, 1846) (Platyhelmintha). Physis 26: 405-410.

Dioni W (1967b) Temnocephalas uruguayas. II. Descripción de Temnocephala talicei n. sp. y notas sobre T. axenos Monticelli (Platyhelmintha). Physis 26: 477-484.

Dioni W (1967c) Temnocephalas argentinas. II. Las Temnocephala de Aegla del Museo Argentino de Ciencias Naturales "Bernardino Rivadavia" (Platyhelmintha). Physis 26: 509-514.

Dioni W (1967d) Temnocephalas argentinas. III. T. pignalberiae y $T$. santafesina novae especies de Trichodactylus del paraná medio. Acta Zoológica Lilloana 23: 349-360.

Dioni W (1968) Presencia de Temnocephala talicei (Platyhelmintha, Temnocephalidae) en Paraguay. Physis 27: 263-264.

Dioni W (1972) Didymorchis, Temnocephala (Platyhelmintha) y Stratiodrilus (Annelida) vermes epizoicos sobre Aegla y Parastacus (Crustacea: Decapoda) de los Lagos andinopatagónicos: notas taxonómicas y biogeográficas. Acta Zoológica Lilloana 29: 167-180.

Di Persia DH, Radici de Cura MS (1973) Algunas consideraciones acerca de los organismos epibiontes desarrollados sobre Ampullariidae. Physis 32: 309-319.

Dove ADM, Cribb TH (2006) Species accumulation curves and their applications in parasite ecology. Trends in Parasitology 22: 568574. doi: 10.1016/j.pt.2006.09.008

du Preez L, Smit N (2013) Double blow: Alien crayfish infected with invasive temnocephalan in South African waters. South African Journal of Science 109 (9/10), Art. \#2013-0109: 1-4. doi: 10.1590/ sajs.2013/20130109

FAO (2012) Recreation fisheries. Technical guidelines for responsible fisheries. No. 13. Rome, Italy 176, pp.

Ferreira Yuki VL, Damborenea MC, Osorio Mallman MT (1993) Acanthochelys spixii (Duméril et Bibron, 1835) (Chelidae) e Trachemys dorbigni (Duméril et Bibrom, 1835) (Emydidae) (Testudines) como hospedeiros de Temnocephala brevicornis Monticelli, 1889 (Temnocephalidae) (Platyhelminthes). Comunicações do Museu de Ciências e Tecnologia da PUCRS. Série zoologia 6: $75-83$. 
Flecher L, Ponce de León R (1983) Observaciones acerca de la regeneración en Temnocephala iheringi Haswell, 1893 (Platyhelminthes, Turbellaria). Boletín de la Sociedad Zoológica del Uruguay 1: 67-72.

Fujita MK, Leache AD, Burbrink FT, McGuire JA, Moritz C (2012) Coalescent-based species delimitation in an integrative taxonomy. Trends in Ecology and Evolution 27: 480-488. doi: 10.1016/j. tree.2012.04.012

Garcés AC, Puerta L, Tabares Y, Lenis C, Velásquez LE (2013) Temnocephala colombiensis $\mathrm{n}$. sp. (Platyhelminthes: Temnocephalidae) from Antioquia, Colombia. Revista Mexicana de Biodiversidad 84: 1090-1099. doi: 10.7550/rmb.30259

Gelder SR (1999) Zoogeography of branchiobdellidans (Annelida) and temnocephalidans (Platyhelminthes) ectosymbiotic on freshwater crustaceans, and their reactions to one another in vitro. Hydrobiologia 406: 21-31. doi: 10.1023/A:1003755630718

González LE, Ponce de León R, de Vaio RS (1987) Chromosome differences between two species of Temnocephala (Platyhelminthes). Cytobios 49: 85-88.

Haswell WA (1893) A monograph of the Temnocephalidae. Proceedings of the Linnean Society of New South Wales, Macleay Memorial Volume: 93-152.

Herbert B (1987) Notes on diseases and epibionts of Cherax quadricarinatus and C. tenuimanus (Decapoda: Parastacidae). Aquaculture 64: 165-173. doi: 10.1016/0044-8486(87)90322-X

Hijmans RJ, Guarino L, Mathur P (2012) DIVA-GIS version 7.5 manual. California, USA: University of California Davis. Manual available at http://www.diva-gis.org

Hyman LH (1955) Miscellaneous Marine and Terrestrial Flatworms from South America. American Museum Novitates 1742: 1-33.

IUCN (2014) The IUCN Red List of Threatened Species. Version 2014.1. http://www.iucnredlist.org [Downloaded on 12 June 2014]

Ibáñez Herrera N, Jaráb CA (2003) Temnocephala peruensis n. sp. (Turbelaria) parásito de Hypolobocera henrici (Decapoda) del río Marañón (Imaza, Amazonas-Perú). Revista Peruana de Parasitología 16: 55-57.

Jennings JB (1968) A new temnocephalid flatworm from Costa Rica. Journal of Natural History 2: 117-120. doi: 10.1080/0022 2936800770671

Jones TC, Lester RJG (1993) Aspects of the biology and pathogenicity of Diceratocephala boschmai (Platyhelminthes: Temnocephalida), an ectosymbiont on the redclaw crayfish, Cherax quadricarinatus. Australian Journal of Marine and Freshwater Research 44: 927-933. doi: 10.1071/MF9930927

Lamothe-Argumedo R (1968) Redescripción de Temnocephala mexicana Vayssiére, 1898, ectocomensal de crustáceos mexicanos. Anales del Instituto de Biología, Universidad Nacional Autonóma de México, Serie Zoología 39: 1-12.

Lamothe-Argumedo R (1974) Algunas consideraciones sobre el género Temnocephala Blanchard, 1849, y descripción de una especie nueva de Costa Rica. Anales del Instituto de Biología, Universidad Nacional Autonóma de México, Serie Zoología 45: 31-38.

Lamothe-Argumedo R (1980) Un caso raro de parasitismo. Anales del Instituto de Biología, Universidad Nacional Autonóma de México, Serie Zoología 51: 675-682.

Larson ER, Olden JD (2012) Using avatar species to model the potential distribution of emerging invaders. Global Ecology and Biogeography 21: 1114-1125. doi: 10.1111/j.1466-8238.2012.00758.x
Lodge DM, Deines A, Gherardi F, Yeo DCJ, Arcella T, Baldridge AK, Barnes MA, Lindsay W, Chadderton WL, Feder JL, Gantz CA, Howard GH, Jerde CL, Peters BW, Peters JA, Sargent LW, Turner CR, Wittmann ME, Zeng Y (2012) Global introductions of crayfishes: evaluating the impact of species invasions on ecosystem services. Annual Review of Ecology, Evolution, and Systematics 43: 449-472. doi: 10.1146/annurev-ecolsys-111511-103919

Maddison DR, Schulz KS (Eds) (2007) The Tree of Life Web Project. Internet address: http://tolweb.org

Mañé-Garzón F (1960) Didymorchis haswelli n. sp.: Un nuevo Temnocephalida de la cavidad branquial de Parastacus saffordi Faxon. Anales del Museo de Historia Natural (Segunda serie) 7: 1-17.

Martín PR, Estebenet AL, Burela S (2005) Factors affecting the distribution of the commensal Temnocephala iheringi (Platyhelminthes: Temnocephalidae) among the southernmost populations of the apple-snail Pomacea canaliculata (Mollusca: Ampullariidae). Hydrobiologia 545: 45-53. doi: 10.1007/s10750-005-1825-6

Martínez-Aquino A, Brusa F, Damborenea MC (2014a) Los temnocéfalos: simbiontes dulceacuícolas. CONABIO. Biodiversitas 116: $12-14$.

Martínez-Aquino A, Ceccarrelli FS, Eguiarte LE, Vázquez-Domínguez E, Pérez-Ponce de León G (2014b) Do the historical biogeography and evolutionary history of the Digenean Margotrema spp. across Central Mexico mirror those of their freshwater fish hosts (Goodeinae)? PLoS ONE 9(7): e101700. doi: 10.1371/journal.pone.0101700

Martínez-Aquino A, Mendoza-Plamero CA, Aguilar-Aguilar R, PérezPonce de León G (2014c) Checklist of helminth parasites of Goodeinae (Osteichthyes: Cyprinodontiformes: Goodeidae), an endemic subfamily of freshwater fishes from Mexico. Zootaxa 3856: 151191. doi: 10.11646/zootaxa.3856.2.1

Melo GAS (2003) Manual de identificação dos Crustacea. Decapoda de água doce do Brasil. Ed. Loyola, São Paulo, 430 pp.

Merton H (1922) Ergebnisse einer zoologischen Forschungsreise in Brasilien. 1913-1914 von. E. Bresslau,-Nieue Beirage zur Anatomie von Temnocephala. Zoologische Jahrbücher. Abteilung für Anatomie und Ontogenie der Tiere 43: 539-556.

Monticelli FS (1889) Di una nouva specie del genere Temnocephala. Blanchard ectoparassita dei Cheloniani. Fratelli Ferrante, Napoli, 4 pp.

Monticelli FS (1902) Temnocephala digitata n. sp. Bolletino Societa Naturalisti Napoli, Rendiconti 16: 1-309.

Monticelli FS (1903) Temnocephala microdactyla $\mathrm{n}$. sp. Bolletino Museu Zoologie Anatomie Compare Torino 439: 1-3.

Monticelli FS (1913) Brevi communicazione sulle Temnocefale. Bolletino Societa Naturalisti Napoli 26: 7-8.

Moquin-Tandon A (1846) Monographie de la famille des Hirudinées, Nouvelle edition. J.-B. Bailliere, Paris, 448 pp.

Moretto HJA (1978) Presencia de Temnocephala (Temnocephalida, Platyhelminthes) en hemípteros acuáticos. Ciencia e Investigación 34: 95-99.

Noreña C, Damborenea C, Brusa F, Escobedo M (2006) Free-living Platyhelminthes of the Pacaya-Samiria National Reserve, a Peruvian Amazon floodplain. Zootaxa. 1313: 39-55.

Novelli LA, Sousa BM, Carvalho AR, Bessa ECA, Souzalima S (2009) Ocorrência de Temnocephala brevicornis Monticelli, 1889 (Platyhelminthes, Temnocephalidae) associada a Hydromedusa maximiliani (Mikan, 1820) (Testudines, Chelidae) em Juiz de Fora, Minas Gerais, Brasil. Revista Brasileira de Zoociências 11: 175-179. 
Ohtaka A, Gelder SR, Nishino M, Niwa N, Ikeda M, Toyama H, Cui Y-D, He X-B, Wong H-Z, Chen R-O, Wang S (2012) Distributions of two ectosymbionts, branchiobdellidans (Annelida: Clitellata) and scutariellids (Platyhelminthes: "Turbellaria": Temnocephalida), on atyid shrimp (Arthropoda: Crustacea) in southeast China. Journal of Natural History 46: 1547-1556. doi: 10.1080/00222933.2012.692826

Page RDM, Charleston MA (1998) Trees within trees: phylogeny and historical associations. TREE 13: 356-359. doi: 10.1016/S01695347(98)01438-4

Pereira C, Cuocolo R (1940) Contribuição para o conhecimento da morfologia, bionomia e ecologia de "Temnocephala brevicornis Monticelli, 1889”. Arquivos do Instituto Biológico 11: 367-398.

Pereira C, Cuocolo R (1941) Estudos sobre "Temnocephalidae Monticelli, 1899", com estabelecimento de dois novos gêneros australianos e descrição de duas novas espécies neotrópicas. Arquivos do Instituto Biológico 12: 101-127.

Pérez González MD (1949) Sobre a digestão e a respiracão das Temnocephalas; descricão de uma espécie nova. Boletins da Faculdade de Filosofia, Ciências e Letras, Universidade de São Paulo 14: 277-323.

Pérez-Ponce de León G, Choudhury A (2010) Parasite inventories and DNA-based taxonomy: lessons from helminths of freshwater fishes in a megadiverse country. Journal of Parasitology 96: 236-244. doi: $10.1645 / g e-2239.1$

Ponce de León R (1979) Especies americanas de Temnocephalidea Benham (Platyhelmintha) I. Descripción de Temnocephala rochensis n. sp. de la cámara paleal de Pomacea canaliculata (Lamark). Revista de Biología del Uruguay 7: 39-45.

Ponce de León R (1989) Description of Temnocephala haswelli n. sp. (Platyhelminthes) from mantle cavity of Pomacea canaliculata (Lamarck). Journal of Parasitology 75: 524-526. doi: 10.2307/3282900

Saoud IP, Ghanawi J (2013) A review of the culture and diseases of redclaw crayfish Cherax quadricarinatus (von Martens 1868). Journal of the World Aquaculture Society 44: 1-29. doi: 10.1111/ jwas. 12011

Schlick-Steiner BC, Steiner FM, Seifert B, Stauffer C, Christian E, Crozier RS (2010) Integrative taxonomy: a multisource approach to exploring biodiversity. Annual Review of Entomology 55: 421-438. doi: 10.1146/annurev-ento-112408-085432

Seixas SA, Amato JFR, Amato SB (2010a) Redescription of Temnocephala iheringi (Platyhelminthes: Temnocephalida) based on specimens from Pomacea canaliculata (Mollusca: Ampullariidae) of the state of Rio Grande do Sul, Brazil: the possible type host and type locality. Zoologia 27: 245-257. doi: 10.1590/S198446702010000200012

Seixas SA, Amato JFR, Amato SB (2010b) First report of Temnocephala rochensis (Platyhelminthes: Temnocephalida) from Pomacea canaliculata (Mollusca: Ampullariidae) outside Uruguay: description update based on specimens from the state of Rio Grande do Sul, Brazil. Zoologia 27: 820-828. doi: 10.1590/S198446702010000500019

Seixas SA, Amato JFR, Amato SB (2010c) First report of Temnocephala haswelli (Platyhelminthes: Temnocephalida) in Pomacea canaliculata (Mollusca: Ampullariidae) from Brazil: description update based on specimens from the state of Rio Grande do Sul, Brazil. Zoologia 27: 455-464. doi: 10.1590/S1984-46702010000500019
Seixas SA, Amato JFR, Amato SB (2011) A new species of Temnocephala Blanchard (Platyhelminthes, Temnocephalida) ectosymbiont on Dilocarcinus septemdentatus (Decapoda, Trichodactylidae) from the Brazilian Amazonia. Neotropical Helminthology 5: $201-212$

Sewell KB (2013) Key to the genera and checklist of species of Australian temnocephalans (Temnocephalida). Museum Victoria Science Reports 17: 1-13. http://www.museum.vic.gov.au/sciencereports/

Schockaert ER, Hooge M, Sluys R, Schilling S, Tyler S, Artois T (2008) Global diversity of free living flatworms (Platyhelminthes, "Turbellaria") in freshwater. Hydrobiologia 595: 41-48. doi: 10.1007/ s10750-007-9002-8

Sicard M, Hinsinger J, Le Brun N, Pages S, Boemare N, Moulia C (2006) Interspecific competition between entomopathogenic nematodes (Steinernema) is modified by their bacterial symbionts (Xenorhabdus). BMC Evolutionary Biology 6: 68. http://www.biomedcentral.com/1471-2148/6/68

Soares JF, Oliveira CB, Silva AS, Souza CP, Monteiro SG (2007) Temnocefalídeo em tartaruga de água doce, Hydromedusa tectifera, da região central do Rio Grande do Sul. Ciência Rural 37: 901-903. doi: 10.1590/S0103-84782007000300050, http://www.redalyc.org/ pdf $/ 331 / 33137350 . p d f$

Stendera S, Adrian R, Bonada N, Cañedo-Argüelles M, Hugueny B, Januschke K, Pletterbauer F, Hering D (2012) Drivers and stressors of freshwater biodiversity patterns across different ecosystems and scales: a review. Hydrobiologia 696: 1-28. doi: 10.1007/s10750-0121183-0

Thompson JN (2005) The Geographic Mosaic of Coevolution. University of Chicago Press, Chicago, 443 pp.

Trivinho-Strixino S, Silva FL, Valente-Neto F (2012) First record of larvae of Chironomidae (Insecta, Diptera) as prey of Temnocephala sp. (Platyhelminthes, Temnocephalidae), an ectosymbiont on larvae of Corydalidae (Megaloptera). Revista Brasileira de Entomologia 56: 387-389. doi: 10.1590/S0085-56262012005000046

Tsuchida T, Koga R, Matsumoto S, Fukatsu T (2011) Interspecific symbiont transfection confers a novel ecological trait to the recipient insect. Biology Letters 7: 245-248. doi: 10.1098/rsbl.2010.0699

Tyler S, Schilling S, Hooge M, Bush LF (comp.) (2006-2012) Turbellarian taxonomic database. Version 1.7. http://turbellaria.umaine.edu Van Steenkiste N, Tessens B, Willems W, Backeljau T, Jondelius U, Artois T (2013) A comprehensive molecular phylogeny of Dalytyphloplanida (Platyhelminthes: Rhabdocoela) reveals multiple escapes from the marine environment and origins of symbiotic relationships. PLoS ONE 8(3): e59917. doi: 10.1371/journal. pone. 0059917

Vianna GJC, Melo AL (2002) Aquatic Heteroptera as host of Temnocephala Blanchard (Platyhelminthes: Temnocephalidae) in Minas Gerais, Brazil. Lundiana 3: 151-153.

Volonterio O (2007a) Análisis filogenético de las especies de Temnocephala Blanchard, 1849 (Plathyehelminthes, Temnocephalida) del Uruguay, con énfasis en la evaluación de la monofilia de las especies epizoicas de Ampullariidae (Mollusca, Gastropoda). Ms. Sc. Thesis Facultad de Ciencias, Universidad de la República (PE-DECIBA), Uruguay.

Volonterio O (2007b) A new species of Temnocephala (Platyhelminthes, Temnocephalida) and a description of $T$. axenos from Uruguay. Journal of Natural History 41: 21-24. doi: 10.1080/00222930701360208 
Volonterio O (2009a) First report of the introduction of an australian temnocephalidan into the new world. Journal of Parasitology 95: 120-123. doi: 10.1645/GE-1726.1

Volonterio O (2009b) Redescription and designation of a neotype of Temnocephala talicei Dioni, 1967 (Platyhelminthes: Temnocephalida). Journal of Parasitology 95: 345-348. doi: 10.1645/GE-1733.1

Volonterio O (2010) Two new species of Temnocephala (Platyhelminthes, Temnocephalida) from the South American snake-necked turtle Hydromedusa tectifera (Testudines, Chelidae). Zoological Science 27: 965-970. doi: 10.2108/zsj.27.965

Wacke R (1905) Beiträge zur Kenntnis der Temnocephalen. Zoologische Jahrbücher Supplement 4-6: 1-116.

Witte V, Leingärtner A, Sabaß L, Hashim R, Foitzik S (2008) Symbiont microcosm in an ant society and the diversity of interspecific interactions. Animal Behaviour 76: 1477-1486. doi: 10.1016/j.anbehav.2008.05.010

\section{Supplementary material}

\section{Appendix 1. Host-symbiont temnocephalans list from}

\section{Neotropics}

Authors: Andrés Martínez-Aquino, Francisco Brusa, Cristina Damborenea

Data type: Microsoft Excel file (xls)

Copyright notice: This dataset is made available under the Open Database License (http://opendatacommons.org/licenses/odbl/1.0/). The Open Database License $(\mathrm{ODbL})$ is a license agreement intended to allow users to freely share, modify, and use this Dataset while maintaining this same freedom for others, provided that the original source and author(s) are credited. 